\title{
Article \\ Glycerol Hydrogenolysis with In Situ Hydrogen Produced via Methanol Steam Reforming: The Promoting Effect of Pd on a $\mathrm{Cu} / \mathrm{ZnO} / \mathrm{Al}_{2} \mathrm{O}_{3}$ Catalyst
}

\author{
Yuanqing Liu (D, Chau T. Q. Mai and Flora T. T. Ng *
}

check for

updates

Citation: Liu, Y.; Mai, C.T.Q.; Ng, F.T.T. Glycerol Hydrogenolysis with In Situ Hydrogen Produced via

Methanol Steam Reforming: The Promoting Effect of Pd on a $\mathrm{Cu} / \mathrm{ZnO} / \mathrm{Al}_{2} \mathrm{O}_{3}$ Catalyst. Catalysts 2021, 11, 110. https://doi.org/ 10.3390/catal11010110

Received: 29 December 2020 Accepted: 12 January 2021 Published: 14 January 2021

Publisher's Note: MDPI stays neutral with regard to jurisdictional clai$\mathrm{ms}$ in published maps and institutional affiliations.

Copyright: (C) 2021 by the authors. Licensee MDPI, Basel, Switzerland. This article is an open access article distributed under the terms and conditions of the Creative Commons Attribution (CC BY) license (https:// creativecommons.org/licenses/by/ $4.0 /)$.
Department of Chemical Engineering, University of Waterloo, 200 University Avenue West, Waterloo, ON N2L3G1, Canada; y289liu@uwaterloo.ca (Y.L.); cmaithiquynh@uwaterloo.ca (C.T.Q.M.)

* Correspondence: fttng@uwaterloo.ca

\begin{abstract}
The glycerol hydrogenolysis to produce 1,2-propanediol without using externally supplied hydrogen was investigated using methanol present in crude glycerol to provide in situ hydrogen via its steam reforming reaction. This paper focuses on the promoting effect of $\mathrm{Pd}$ on the reactivity of a $\mathrm{Cu} / \mathrm{Zn} / \mathrm{Al}_{2} \mathrm{O}_{3}$ catalyst. Adding $2 \mathrm{wt} \%$ Pd onto a $\mathrm{Cu} / \mathrm{ZnO} / \mathrm{Al}_{2} \mathrm{O}_{3}$ catalyst significantly improved the selectivity to 1,2-propanediol from $63.0 \%$ to $82.4 \%$ and the glycerol conversion from $70.2 \%$ to $99.4 \%$. This enhancement on the catalytic activity by $\mathrm{Pd}$ is mainly due to the improved hydrogenation of acetol, which is the intermediate formed during the glycerol dehydration. The rapid hydrogenation of acetol can shift the reaction equilibrium of glycerol dehydration forward resulting in a higher glycerol conversion. The improved reducibility of the catalyst by Pd allows the catalyst to be reduced in situ during the reaction preventing any loss of catalyst activity due to any potential oxidation of the catalyst. The catalyst was slightly deactivated when it was firstly recycled resulting in a $5.4 \%$ loss of glycerol conversion due to the aggregation of $\mathrm{Cu}$ and the deactivation became less noticeable upon further recycling.
\end{abstract}

Keywords: glycerol hydrogenolysis; $\mathrm{Cu} / \mathrm{ZnO} / \mathrm{Al}_{2} \mathrm{O}_{3}$ catalysts; Pd promoter; in situ hydrogen; methanol steam reforming; acetol hydrogenation

\section{Introduction}

In recent years, in order to solve the issue of climate change and reduce the dependence on fossil fuel, biodiesel industries have been rapidly developed all over the world by governments in the forms of tax incentives and mandatory blending among other incentives. It is expected for biodiesel to be growing in the next decade [1]. Propane-1,2,3-triol, also known as glycerol, is the major byproduct in the biodiesel production process via a transesterification reaction of the triglycerides. Since the production of global biodiesel has rapidly increased, a large amount of glycerol has entered into the market causing not only the market value of glycerol to drop but, in addition, there are associated environmental hazards in handling such a large amount of surplus impure glycerol [2]. Glycerol has been considered as one of the major building block chemicals derived from biomass as it can be converted to a wide range of important chemicals that have normally been produced from petroleum based resources [2,3]. The transformation from this biomass derived glycerol into the value added chemicals has been of great interest not only to lower the production cost of biodiesel industry but more importantly to produce green chemicals from non-fossil resources. Propane-1,2-diol, also known as 1,2-propanediol (1,2-PD), is a valuable chemical that can be used in a wide range of applications such as anti-freeze and pharmaceutical additives. Currently commercial production of 1,2-PD is via the hydration of propylene oxide, which is derived from petroleum resources [4]. There were many reports on the hydrogenolysis of aqueous glycerol with high pressure externally supplied molecular 
hydrogen. Glycerol was firstly dehydrated into 1-hydroxypropane-2-one, known as acetol, followed by acetol hydrogenation to form 1,2-PD [5-7].

However, the utilization of high pressure molecular hydrogen has disadvantages for the conventionally reported processes. The high hydrogen pressure may cause safety issues due to the high diffusivity and flammability of molecular hydrogen [8,9]. Biodiesel plants normally do not have hydrogen plants on site. Thus, the use of external hydrogen also introduces additional costs for hydrogen storage and transportation in a large scale commercialization process $[10,11]$. Therefore, alternative approaches without using molecular hydrogen have drawn great interest from many researchers. One approach is to produce in situ hydrogen via aqueous phase reforming (APR) of glycerol, which is also the feedstock for producing 1,2-PD [12-21]. In this process, although no additional hydrogen donor is needed, $\mathrm{Pt}$ based catalysts are usually used to obtain a higher 1,2-PD selectivity compared with $\mathrm{Cu}$ and $\mathrm{Ni}$ based catalysts. The reported 1,2-PD selectivity varies from $35.3 \%$ to $70.2 \%$ using Pt based catalysts. The selectivity of 1,2-PD with the in situ hydrogen produced via glycerol APR reaction is reported to be low mainly due to the formation of light alcohol via glycerol C-C cleavage and formation of short chain alkane resulting in lower commercial values for the products [22]. Another approach for glycerol hydrogenolysis to produce 1,2-PD is via the catalytic transfer hydrogenated $(\mathrm{CTH})$ reaction such that the in situ hydrogen is formed from a hydrogen donor, which is externally added into the reaction mixture. Musolino et al. in 2009 firstly reported the $\mathrm{CTH}$ process for 1,2-PD production using a $\mathrm{Fe}_{3} \mathrm{O}_{4}$ supported $\mathrm{Pd}$ catalyst with propan-2-ol (2-propanol) as the hydrogen donor $[23,24]$. Various hydrogen donors have been widely reported such as 2-propanol [9,25-28], formic acid [9,27,29,30], ethanol [9,23,28,31], butan1-ol (1-butanol) [9,28], butan-2-ol (2-butanol) [9] and ethane-1,2-diol, known as, ethylene glycol (EG) [9]. The 1,2-PD selectivity normally can be greatly improved in the CTH process compared with the glycerol APR process; however, additional costs will be incurred due to the purchase and storage of the external hydrogen donor. Furthermore, the formation of byproducts such as ketones and aldehydes via the dehydrogenations of the hydrogen donors, will make the production more costly due to the additional downstream separation process on its large scale commercialization.

Methanol has been considered as an ideal hydrogen donor for glycerol hydrogenolysis to produce 1,2-PD such that the in situ hydrogen produced from methanol steam reforming is used for the acetol hydrogenation reaction. Methanol has its own advantages over other hydrogen donors. First of all, the crude glycerol stream has the unreacted methanol due to the excess amount of methanol added for the transesterification process in biodiesel plants. Crude glycerol can be directly used as feedstock before methanol recovery; secondly, methanol has the highest $\mathrm{H} / \mathrm{C}$ ratio compared with other reported hydrogen donors. Furthermore, the reforming of methanol does not involve $\mathrm{C}-\mathrm{C}$ cleavage thus resulting in less byproduct formation. It has been reported that the selectivity of 1,2-PD in the glycerol hydrogenolysis process is highly dependent on the efficiency of acetol hydrogenation since the formation of different undesired byproducts was due to the condensation of acetol with different alcohols and hence can result in a low 1,2-PD selectivity when acetol cannot be effectively hydrogenated $[5,32,33]$. Our group has developed the process of glycerol hydrogenolysis to produce 1,2-PD with the in situ hydrogen from methanol steam reforming using a $\mathrm{Cu} / \mathrm{ZnO} / \mathrm{Al}_{2} \mathrm{O}_{3}$ catalyst and reported that the major challenge to have a high 1,2-PD selectivity is to achieve a rapid acetol hydrogenation reaction [34,35]. The promoting effect of $\mathrm{Ni}$ on the $\mathrm{Cu} / \mathrm{ZnO} / \mathrm{Al}_{2} \mathrm{O}_{3}$ catalyst was investigated and the results showed that with $5 \% \mathrm{Ni}$ added, the 1,2-PD selectivity was improved from $70.7 \%$ to $85.5 \%$ at $220{ }^{\circ} \mathrm{C}$ using $3 \mathrm{wt} \%$ catalyst, $20 \mathrm{wt} \%$ glycerol feedstock, after $8 \mathrm{~h}$ reaction time. The improvement of 1,2-PD selectivity was mainly attributed to the promoting effect of $\mathrm{Ni}$ on the catalytic activities for acetol hydrogenation to ensure that the acetol can be effectively hydrogenated; therefore, the formation of byproducts via side reactions caused by acetol could be eliminated [35]. Professor Lemonidou's group has also thoroughly studied this process using $\mathrm{Cu} / \mathrm{ZnO} / \mathrm{Al}_{2} \mathrm{O}_{3}$ catalysts [36,37] and Pt supported on Fe modified $\mathrm{Al}_{2} \mathrm{O}_{3}$ 
catalysts [38]. A mechanistic study has also been carried out by the same group for this process confirming that the 1,2-PD selectivity strongly depends on the amount of hydrogen provided via methanol steam reforming [39]. In order to improve the 1,2-PD selectivity in the process of glycerol hydrogenolysis using in situ hydrogen from methanol steam reforming, minimizing the amount and the residence time of acetol present in the reaction mixture is the key factor and it can be achieved by improving the catalytic activity for acetol hydrogenation. Scheme 1 illustrates the pathway of the reaction system. It has been reported by various kinetic studies that the glycerol dehydration reaction is an equilibrium limited reaction $[33,40,41]$. A rapid acetol hydrogenation reaction does not only improve the 1,2-PD selectivity by prohibiting the formation of other byproducts due to side reactions of acetol but also shifts the equilibrium of glycerol dehydration forward resulting in a higher glycerol conversion (Scheme 1).

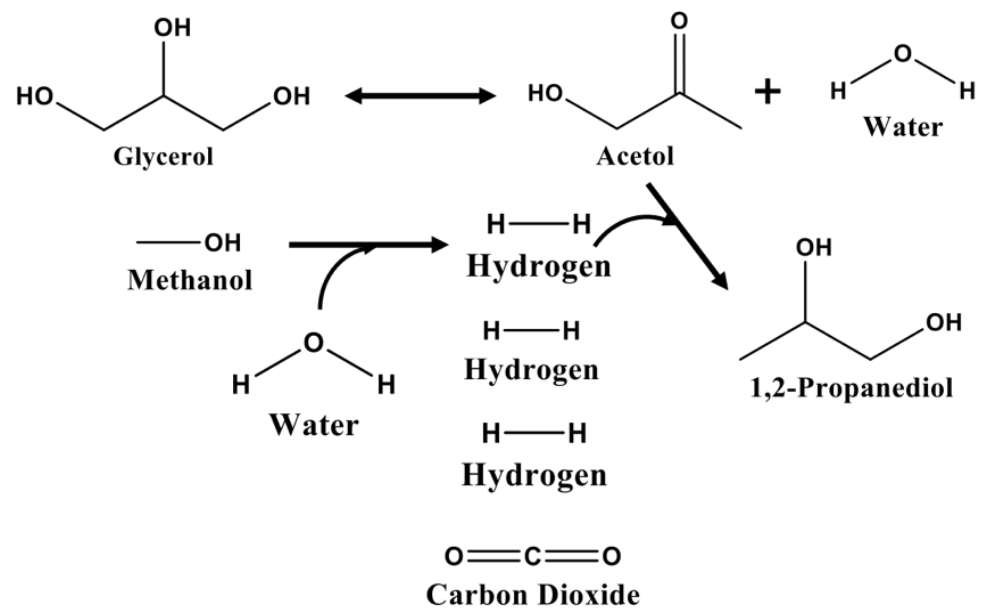

Scheme 1. Reaction pathway of glycerol hydrogenolysis to produce 1,2-PD with in situ hydrogen produced from methanol steam reforming.

Pd has been extensively used in different hydrogenation processes due to its superior hydrogenation activity. It has been widely reported that a small amount of Pd doped onto a $\mathrm{Cu}$ based catalyst can significantly improve its hydrogenation activity due to the hydrogen spillover effect [42-44]. Furthermore, $\mathrm{Pd}-\mathrm{Cu}$ based catalysts have also been used extensively as catalysts for methanol steam reforming processes [45-47]. In a glycerol hydrogenolysis processes using molecular hydrogen, $\mathrm{Pd}$ has also been reported to be an effective promoter for $\mathrm{Cu}$ based catalysts [48-50]. Therefore, adding Pd onto a $\mathrm{Cu} / \mathrm{ZnO} / \mathrm{Al}_{2} \mathrm{O}_{3}$ catalyst could improve the catalyst activity in a glycerol hydrogenolysis process using the in situ hydrogen produced via methanol steam reforming due to the enhancement for the catalyst hydrogenation activity. In this work, the promoting effect of $\mathrm{Pd}$ on the $\mathrm{Cu} / \mathrm{ZnO} / \mathrm{Al}_{2} \mathrm{O}_{3}$ catalyst for glycerol hydrogenolysis using in situ hydrogen from methanol steam reforming and acetol hydrogenation were investigated. The catalyst characterization was carried out to study the relationship between the physicochemical properties of the catalysts and their reactivities.

\section{Results and Discussion}

\subsection{Catalyst Characterizations}

2.1.1. Physicochemical Properties of $\mathrm{Cu} / \mathrm{ZnO} / \mathrm{Al}_{2} \mathrm{O}_{3}$ and Its Supported Pd Catalysts

As reported in our previous work, the $\mathrm{Cu} / \mathrm{ZnO} / \mathrm{Al}_{2} \mathrm{O}_{3}$ catalyst (referred to as $\mathrm{CZA}$ ) prepared via an oxalate gel-coprecipitation method exhibited superior activity compared with the catalysts prepared via alkaline co-precipitation; the optimum $\mathrm{Cu} / \mathrm{Zn} / \mathrm{Al}$ molar ratio was determined to be 35/35/30 in this reaction system [35]. The same catalyst was used throughout this work as the benchmark for the reaction with Pd loaded onto the CZA catalyst to investigate the promoting effect of $\mathrm{Pd}$ (referred to as $\mathrm{xPd}-\mathrm{CZA}$ where $\mathrm{x}$ is the 
weight percentage of Pd loading). Table 1 compares some physicochemical properties of the CZA and 2Pd-CZA catalysts. It should be noted that with $2 \mathrm{wt} \% \mathrm{Pd}$ loaded on to the CZA catalyst, the BET (Brunauer-Emmett-Teller) surface area, Cu surface area determined by $\mathrm{N}_{2} \mathrm{O}$ reactive frontal chromatography $(\mathrm{RFC})$ and the $\mathrm{CuO}$ particle size calculated via the Scherrer equation from the $\mathrm{X}$-ray diffraction $(\mathrm{XRD})$ profile are not significantly changed compared with the CZA catalyst. The $\mathrm{CuO}$ particle size of the 2Pd-CZA catalyst is found to be slightly increased, which might be an experimental error or possibly due to a slight sintering of the particles during the calcination of the Pd impregnated catalyst. The effect of $\mathrm{Pd}$ on the acidity of the catalyst was evaluated by $\mathrm{NH}_{3}$ temperature programmed desorption (TPD) and the results are illustrated in Figure 1. Three distinct peaks can be observed for the CZA catalyst, which range from 50 to $290{ }^{\circ} \mathrm{C}$, from 290 to $470{ }^{\circ} \mathrm{C}$ and from 590 to $800{ }^{\circ} \mathrm{C}$, representing the weak acidic sites, medium acidic sites and strong acidic sites, respectively (Figure 1a). With $2 \mathrm{wt} \%$ Pd loaded onto the CZA catalyst, three peaks are observed in the same temperature ranges revealing that the introduction of $\mathrm{Pd}$ did not generate new acidic sites (Figure $1 b$ ). In addition, by loading $2 \mathrm{wt} \% \mathrm{Pd}$ onto the CZA catalyst the peak of the strong acidic site is slightly shrunken and the amount of the strong acidic site is reduced from $0.075 \mathrm{mmolNH}_{3} / \mathrm{g}$-cat to $0.065 \mathrm{mmolNH}_{3} / \mathrm{g}$-cat as listed in Table 1 . This is possibly because Pd can cover some acidic sites or the slightly larger particle size formed due to sintering during the calcination can result in a reduced amount of acidic site on the surface of the catalyst.

Table 1. Physicochemical properties of the $\mathrm{Cu} / \mathrm{ZnO} / \mathrm{Al}_{2} \mathrm{O}_{3}$ catalyst and its supported Pd catalyst.

\begin{tabular}{|c|c|c|c|c|}
\hline Catalysts & $\begin{array}{l}\text { BET Surface Area } \\
\left(\mathrm{m}^{2} / \mathrm{g} \text {-cat }\right)\end{array}$ & $\begin{array}{c}\text { CuO Particle Size }{ }^{1} \\
(\mathrm{~nm})\end{array}$ & $\begin{array}{l}\text { Cu Surface Area } \\
\left(\mathrm{m}^{2} / \mathrm{g} \text {-cat }\right)\end{array}$ & $\begin{array}{c}\text { Strong Acidic Sites } \\
\text { (mmolNH } \\
\text { (m-g-cat) }\end{array}$ \\
\hline $\mathrm{CZA}^{3}$ & 86.6 & 7.4 & 18.0 & 0.075 \\
\hline $2 \mathrm{Pd}-\mathrm{CZA}^{4}$ & 84.6 & 7.6 & 17.8 & 0.065 \\
\hline
\end{tabular}

${ }^{1}$ Calculated via Scherrer equation based on the XRD profiles. ${ }^{2} 600{ }^{\circ} \mathrm{C}-800{ }^{\circ} \mathrm{C}$ in $\mathrm{NH}_{3}$ TPD. ${ }^{3} \mathrm{Cu} / \mathrm{Zn} / \mathrm{Al}(\mathrm{molar})=35 / 35 / 30 .{ }^{4}$ Support: $\mathrm{Cu} / \mathrm{ZnO} / \mathrm{Al}_{2} \mathrm{O}_{3}$ catalyst $(\mathrm{CZA})^{3}$.

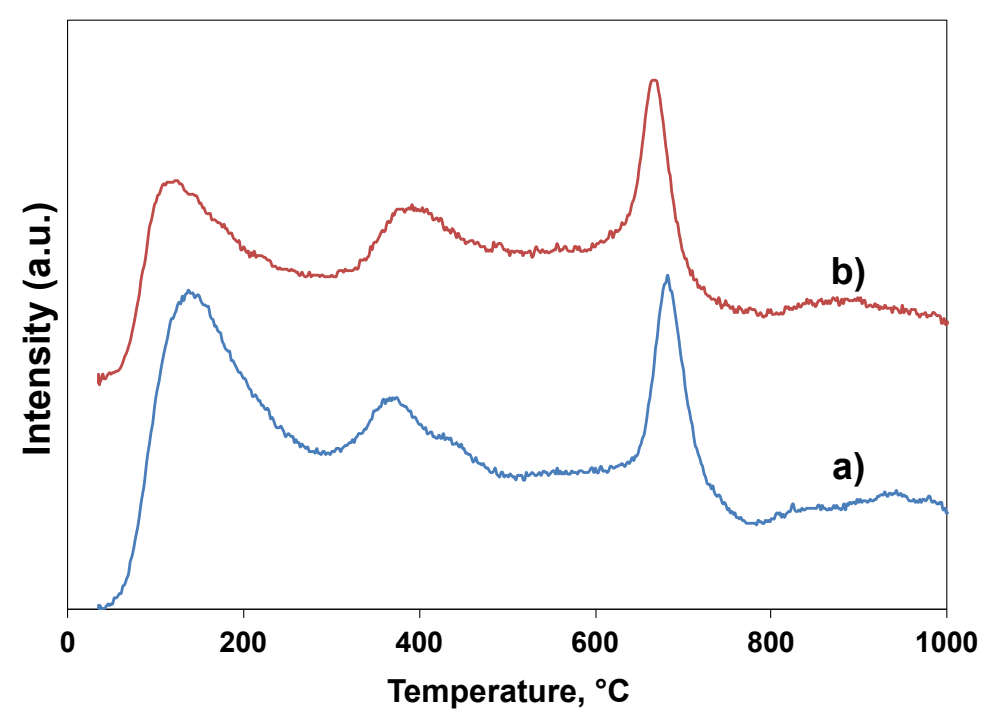

Figure 1. $\mathrm{NH}_{3}$ temperature programmed desorption (TPD) profiles for: (a) CZA; (b) 2 Pd-CZA. CZA: $\mathrm{Cu} / \mathrm{Zn} / \mathrm{Al}($ molar$)=35 / 35 / 30$. All traces have been displaced for clarity.

\subsubsection{Temperature Programmed Reduction (TPR)}

The reducibility of the CZA catalyst and its supported Pd catalysts were investigated by temperature programmed reduction (TPR) analyses and the profiles are illustrated in Figure 2. For the CZA catalyst, the hydrogen consumption peak starts at $190^{\circ} \mathrm{C}$ and reaches its maxima at $270{ }^{\circ} \mathrm{C}$ and completes at $335^{\circ} \mathrm{C}$ (Figure 2a). With $2 \mathrm{wt} \% \mathrm{Pd}$ loaded onto the 
CZA catalyst, the peak shifts to $133^{\circ} \mathrm{C}$ and the reduction starts from $45^{\circ} \mathrm{C}$ and completes at $200^{\circ} \mathrm{C}$ (Figure $2 \mathrm{~b}$ ). It is clear that $\mathrm{Pd}$ can significantly improve the reducibility of a CZA catalyst so that the catalyst can be reduced at a lower temperature. It has been reported that the reduction of $\mathrm{PdO}$ can occur at room temperature and can be completed below $100{ }^{\circ} \mathrm{C}$ [51-53]. During the reduction process, $\mathrm{H}_{2}$ molecules are dissociatively adsorbed onto a PdO surface in the form of surface hydrogen atoms at a very low temperature and subsequently reduced the $\mathrm{PdO}$ into $\mathrm{Pd}$. Then the atomic hydrogen on $\mathrm{Pd}$ surface can rapidly spill over to adjacent $\mathrm{CuO}$ due to its high diffusivity facilitating the reduction of $\mathrm{CuO}$ at a much lower temperature [48]. However, for a CZA catalyst, the dissociative adsorption of $\mathrm{H}_{2}$ molecule on a $\mathrm{CuO}$ surface is a much more difficult process compared to that on the $\mathrm{PdO}$ surface so that a higher temperature is required for the catalyst reduction [44,54].

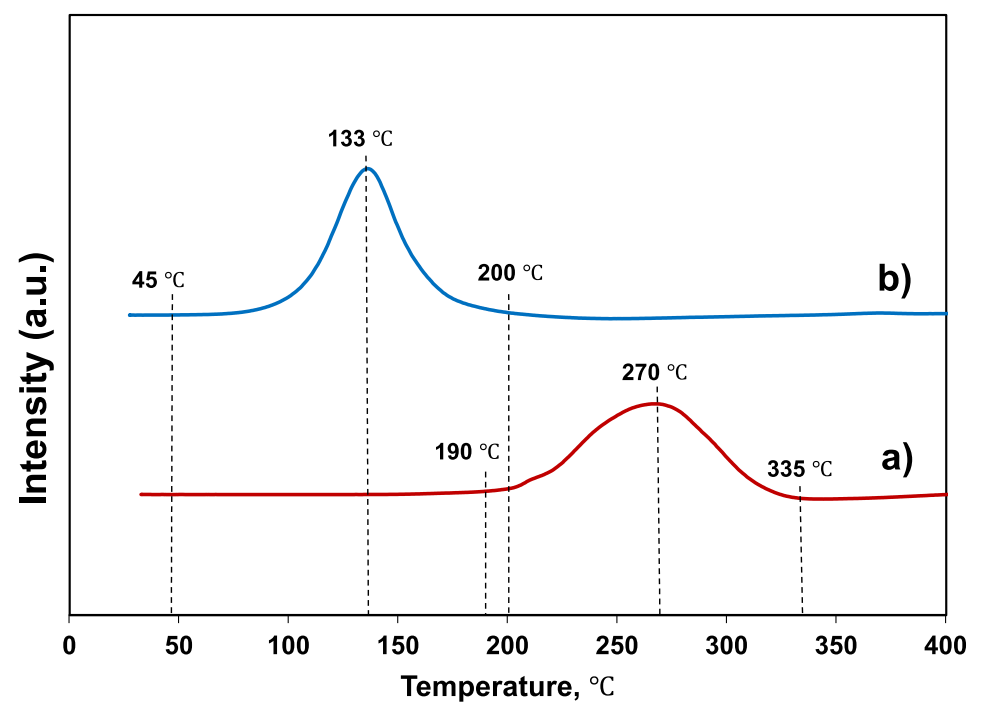

Figure 2. Temperature programmed reduction (TPR) profiles for: (a) CZA; (b) 2Pd-CZA. CZA: $\mathrm{Cu} / \mathrm{Zn} / \mathrm{Al}($ molar $)=35 / 35 / 30$. All traces have been displaced for clarity.

\subsubsection{X-ray Diffraction (XRD)}

The crystalline phases of the catalysts were studied by XRD analyses, the particle sizes were calculated based on the Scherrer equation as tabulated in Table 1. Figure 3 compares the XRD profiles of the calcined CZA and 2Pd-CZA catalysts. The crystallinity of the CZA catalyst prepared via the oxalate gel-coprecipitation method has been reported in our previous paper [35] as well as shown in Figure 3a. It can be seen that the particles were well mixed and homogeneously distributed as suggested by the very broad peaks of $\mathrm{CuO}\left(2 \theta\right.$ at $35.6^{\circ}, 38.7^{\circ}$ and $\left.48.9^{\circ}\right)$ and $\mathrm{ZnO}\left(2 \theta\right.$ at $\left.32.4^{\circ}\right)$. For the $2 \mathrm{wt} \% \mathrm{Pd}$ loaded onto the CZA catalyst, the crystal structure was not significantly changed and a similar XRD profile is obtained, as illustrated in Figure $3 \mathrm{~b}$. No PdO peak is observed probably due to the overlapping of the characteristic peaks between $\mathrm{PdO}$ and $\mathrm{ZnO}$ when a very low amount of $\mathrm{Pd}$ was loaded $\left(2 \theta\right.$ at $\left.33.9^{\circ}\right)[55,56]$. It is also possible that $\mathrm{PdO}$ particles are in a very low crystallinity and homogeneously dispersed over the catalyst [56]. 


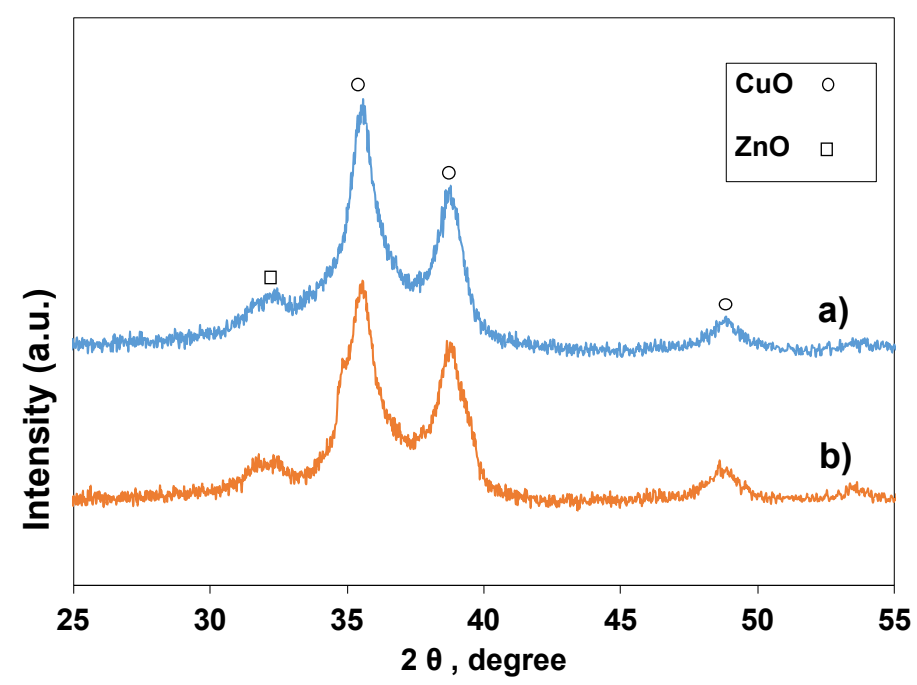

Figure 3. X-ray diffraction (XRD) profiles for the calcined catalysts: (a) 2Pd-CZA; (b) CZA. CZA: $\mathrm{Cu} / \mathrm{Zn} / \mathrm{Al}$ (molar) $=35 / 35 / 30$. All traces have been displaced for clarity.

\subsubsection{X-ray Photoelectron Spectroscopy (XPS)}

The X-ray photoelectron spectroscopy analyses of the CZA supported Pd catalysts were performed to identify the chemical oxidation states of different elements present in the catalysts. The XPS spectra of Pd $3 d$ for different catalysts are shown in Figure 4. It is clearly seen in Figure 4a that Pd in the unreduced and fresh 2Pd-CZA is present as $\mathrm{PdO}$ as two peaks of $\mathrm{Pd} 3 \mathrm{~d}_{5 / 2}$ and $\mathrm{Pd} 3 \mathrm{~d}_{3 / 2}$ at 336.0 and $341.5 \mathrm{eV}$, respectively, represent the binding energies of $\mathrm{PdO}$. After reduction, the $\mathrm{Pd} 3 \mathrm{~d}_{5 / 2}$ and $\mathrm{Pd} 3 \mathrm{~d}_{3 / 2}$ peaks shift to 334.5 and $340.0 \mathrm{eV}$, respectively, which represent the binding energies for $\mathrm{Pd}^{0}$ (Figure $4 \mathrm{~b}$ ). When the Pd is reduced, such a downward shift of more than $1 \mathrm{eV}$ has also been reported elsewhere [57,58]. It is also noticed in Figure 4c,d that there is no change in the Pd $3 d$ spectra for the spent catalysts recycled from the reaction. Thus, Pd on the catalyst was not reoxidized to $\mathrm{PdO}$ during the reaction and still remained in the zero oxidation state after recycling.

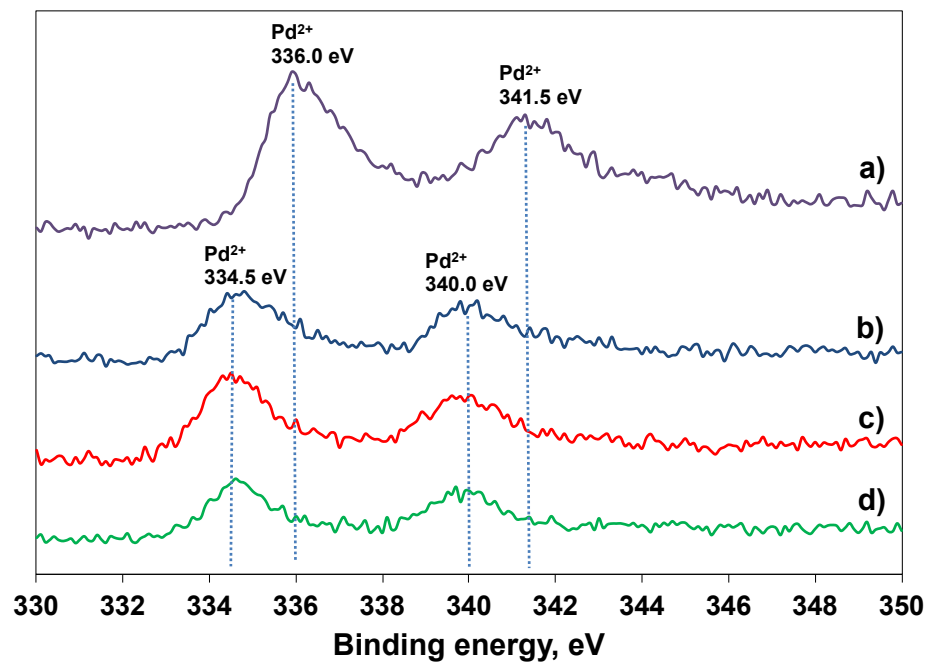

Figure 4. X-ray photoelectron spectroscopy (XPS) spectra of Pd3d for 2Pd-CZA catalysts: (a) unreduced fresh catalyst; (b) reduced fresh catalyst; (c) unreduced spent catalyst; (d) reduced spent catalyst. CZA: $\mathrm{Cu} / \mathrm{Zn} / \mathrm{Al}$ (molar) = 35/35/30. All traces have been displaced for clarity.

The XPS spectra of $\mathrm{Cu} 2 \mathrm{p}$ for the 2Pd-CZA catalysts are shown in Figure 5. The two peaks at binding energies of 952.8 and $932.5 \mathrm{eV}$ are attributed to the $\mathrm{Cu} 2 \mathrm{p}_{1 / 2}$ and $\mathrm{Cu} 2 \mathrm{p}_{3 / 2}$ 
spectra of $\mathrm{Cu}^{0}$; the four peaks at binding energies of $962.5,954.5,942.5$ and $934.3 \mathrm{eV}$ are attributed to the $\mathrm{Cu} 2 \mathrm{p}_{1 / 2}$ and $\mathrm{Cu} 2 \mathrm{p}_{3 / 2}$ spectra of $\mathrm{Cu}^{2+}$ with two main peaks at 954.5 and $934.3 \mathrm{eV}$ and two strong satellite peaks at 962.5 and $942.5 \mathrm{eV}[59,60]$. For the unreduced fresh 2Pd-CZA catalyst (Figure 5a), the four peaks at the binding energies representing $\mathrm{Cu}^{2+}$ can be clearly observed. This result is in good agreement with the discussion in the XRD data in the previous section that $\mathrm{Cu}$ exists in a form of $\mathrm{CuO}$ after calcination. After reduction, the $\mathrm{Cu}$ in the catalyst is mainly in the metallic $\mathrm{Cu}$ form as only the peaks at the binding energies for $\mathrm{Cu}^{0}$ can be observed indicating that the reduction process is efficient to reduce $\mathrm{CuO}$ to metallic $\mathrm{Cu}$ (Figure $5 \mathrm{~b}$ ). It is noticed that for the recycled catalyst after the reaction as illustrated in Figure 5c, the two peaks at 932.5 and $952.8 \mathrm{eV}$ representing $\mathrm{Cu}^{0}$ are still the dominant peaks and a peak at $942.5 \mathrm{eV}$ attributed to $\mathrm{Cu}^{2+}$ with a very low intensity can be observed revealing that a slight oxidation of $\mathrm{Cu}$ may occur during the reaction or the catalyst recycling process. When the spent catalyst was reduced, no peak of $\mathrm{Cu}^{2+}$ was detected but only the peaks representing $\mathrm{Cu}^{0}$ were observed (Figure $5 \mathrm{~d}$ ). Due to the overlap of the binding energies between $\mathrm{Cu}^{0}$ and $\mathrm{Cu}^{+}[61,62]$, the existence of $\mathrm{Cu}_{2} \mathrm{O}$ in the reduced catalysts cannot be precisely identified especially if it is in an insignificant amount coexisting with $\mathrm{Cu}^{0}$.

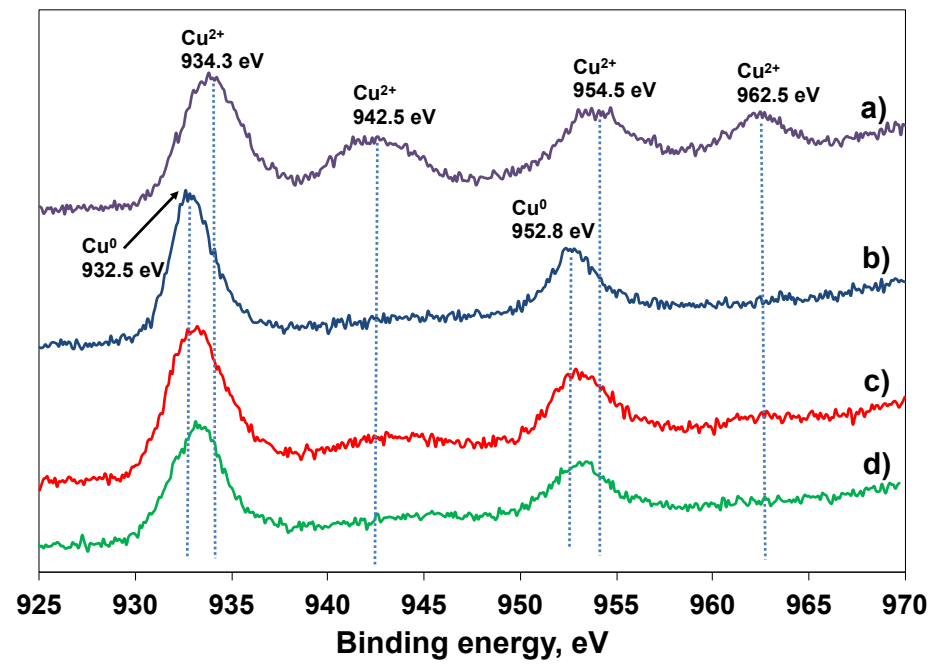

Figure 5. X-ray photoelectron spectroscopy (XPS) spectra of $\mathrm{Cu} 2 \mathrm{p}$ for 2Pd-CZA catalysts: (a) unreduced fresh catalyst; (b) reduced fresh catalyst; (c) unreduced spent catalyst; (d) reduced spent catalyst. $\mathrm{CZA}: \mathrm{Cu} / \mathrm{Zn} / \mathrm{Al}$ (molar) = 35/35/30. All traces have been displaced for clarity.

\subsection{Catalytic Activity}

2.2.1. Effect of $\mathrm{Pd}$ Loading on the Catalytic Activities of $\mathrm{Cu} / \mathrm{ZnO} / \mathrm{Al}_{2} \mathrm{O}_{3}$ Catalysts for Glycerol Hydrogenolysis via In Situ Hydrogen from Methanol Steam Reforming

It has been extensively studied and widely reported that acetol, the intermediate from glycerol dehydration, can form different byproducts via the side reactions between acetol and different alcohols $[32,34,35]$. The key factor of maximizing the 1,2-PD selectivity is to minimize the acetol content in the reaction mixture during the process by effectively hydrogenating acetol. Pd was selected in this work as the promoter of a CZA catalyst to improve the selectivity of 1,2-PD in this process since $\mathrm{Pd}$ is well known as a promising promoter to improve the hydrogenation activity of a $\mathrm{Cu}$ based catalyst via a spillover effect in a wide range of catalytic hydrogenation applications [42-44]. This reaction system has been mathematically verified in our previous work to be in absence of external liquid to solid mass transfer limitation and intraparticle diffusion limitation [35]. Same conclusions have been verified by Yfanti et al. theoretically and experimentally for the same reaction system with similar reaction conditions [39]. Therefore, all the reactions were carried out in the kinetic control regime. 
Different amounts of $\mathrm{Pd}(0.5 \mathrm{wt} \%, 1 \mathrm{wt} \%, 2 \mathrm{wt} \%$ and $3 \mathrm{wt} \%)$ were loaded onto the CZA catalysts via an impregnation method. Other Pd loading methods have been investigated and compared as introduced in A1 in the supplementary material. The comparison of the activities of the catalysts is listed in Table 2. It is clear that with Pd added onto a CZA catalyst, the glycerol conversions and 1,2-PD selectivities were significantly improved. At $0.5 \mathrm{wt} \%$ Pd loading, compared with using a CZA catalyst without Pd loading the glycerol conversion and 1,2-PD selectivity were improved from $70.2 \%$ to $80.5 \%$ and $63.0 \%$ to $69.6 \%$, respectively. At $2 \mathrm{wt} \% \mathrm{Pd}$ loading, the glycerol was almost completely converted and the 1,2-PD selectivity was improved to $82.4 \%$; the selectivity of other undesired products, which were formed via the side reactions of acetol, was significantly reduced from $25.7 \%$ to only $12.7 \%$. When the Pd loading was further increased from $2 \mathrm{wt} \%$ to $3 \mathrm{wt} \%$, it was found that the 1,2-PD selectivity was not significantly changed; however, with $3 \mathrm{wt} \% \mathrm{Pd}$ added, the other undesired byproducts selectivity was further reduced to $10.4 \%$ but the selectivity of ethylene glycol (EG) was increased from $4.5 \%$ to $6.8 \%$ hence lowering the 1,2-PD selectivity. Thus, $2 \mathrm{wt} \% \mathrm{Pd}$ was selected as the optimum Pd loading onto a CZA catalyst for further study. It has been generally accepted and widely reported that the low selectivity was mainly due to the lack of hydrogen available for acetol hydrogenation when a CZA catalyst was used [35,37]. The 2Pd-CZA catalyst was used in the reaction system with molecular hydrogen initially added instead of nitrogen. The 1,2-PD selectivity was found to be improved to $92.3 \%$ and no other byproduct via side reactions caused by acetol was formed. The results suggest that the formation of other byproducts is strongly related to the hydrogen availability when a Pd promoted CZA catalyst is used. A $2 \mathrm{wt} \%$ $\mathrm{Pd}$ supported on $\mathrm{ZnO}$ catalyst (2Pd-ZnO) was used without $\mathrm{Cu}$ to investigate the effect of $\mathrm{Pd}$ on glycerol dehydration as it has been claimed by numerous reports that $\mathrm{ZnO}$ is not active for glycerol dehydration reaction $[35,63]$. The glycerol conversion using a $2 \mathrm{Pd}-\mathrm{ZnO}$ catalyst was $83.0 \%$, which was nearly $13 \%$ higher than the glycerol conversion using a CZA catalyst suggesting that Pd is active for glycerol dehydration. However, the 1,2-PD selectivity was only $49.7 \%$ with $2 \mathrm{Pd}-\mathrm{ZnO}$, which is lower than the 1,2-PD selectivities using the CZA catalysts with various amounts of $\mathrm{Pd}$ loaded. The process with the optimized catalyst (2Pd-CZA) was repeated four times. The statistical analysis indicated that the repeatability was satisfactory, as demonstrated in A2 in the supplementary documents.

Table 2. Effect of Pd loading on the CZA catalytic activity for glycerol hydrogenolysis with in situ hydrogen from methanol steam reforming ${ }^{1}$.

\begin{tabular}{|c|c|c|c|c|c|}
\hline \multirow[b]{2}{*}{ Catalysts } & \multirow{2}{*}{$\begin{array}{c}\text { Glycerol } \\
\text { Conversion } \\
\%\end{array}$} & \multicolumn{4}{|c|}{ Selectivity } \\
\hline & & $\begin{array}{c}\text { 1,2-PD } \\
\%\end{array}$ & $\begin{array}{c}\text { Acetol } \\
\%\end{array}$ & $\begin{array}{c}\text { EG } \\
\%\end{array}$ & $\begin{array}{c}\text { Others } \\
\%\end{array}$ \\
\hline $\mathrm{CZA}^{2}$ & 70.2 & 63.0 & 8.0 & 3.2 & 25.7 \\
\hline $0.5 \mathrm{Pd}-\mathrm{CZA}^{3}$ & 80.5 & 69.6 & 4.9 & 3.9 & 21.7 \\
\hline $1 \mathrm{Pd}-\mathrm{CZA}^{3}$ & 90.0 & 79.6 & 1.8 & 4.1 & 14.5 \\
\hline $2 \mathrm{Pd}-\mathrm{CZA}^{3,6}$ & 99.4 & 82.4 & 0.4 & 4.5 & 12.7 \\
\hline $3 \mathrm{Pd}-\mathrm{CZA}^{3}$ & 100.0 & 82.8 & 0.0 & 6.8 & 10.4 \\
\hline $2 \mathrm{Pd}-\mathrm{CZA}^{3,4}$ & 100.0 & 92.3 & 0.0 & 7.5 & 0.0 \\
\hline 2Pd-ZnO & 83.0 & 49.7 & 11.6 & 2.9 & 35.8 \\
\hline $2 \mathrm{Pd}-\mathrm{CZA}^{3,5}$ & 99.0 & 77.3 & 0.9 & 3.5 & 18.3 \\
\hline $\mathrm{CZA}^{2,5}$ & 11.0 & 34.1 & 26.9 & 0.0 & 38.9 \\
\hline
\end{tabular}

${ }^{1}$ Reaction conditions: $220{ }^{\circ} \mathrm{C}, 1.5 \mathrm{MPa} \mathrm{N}, 20 \mathrm{wt} \%$ glycerol, water/methanol molar ratio $=1.2,3 \mathrm{wt} \%$ catalyst with respect to total feed mixture, $6 \mathrm{~h}$ reaction time, $500 \mathrm{RPM} .{ }^{2} \mathrm{Cu} / \mathrm{Zn} / \mathrm{Al}$ (molar) $=35 / 35 / 30 .{ }^{3}$ Support: $\mathrm{CZA}^{2}$. ${ }^{4} 1.5 \mathrm{MPa} \mathrm{H} \mathrm{H}_{2}$ instead of $\mathrm{N}_{2} .{ }^{5}$ Unreduced catalyst. ${ }^{6} 95 \%$ Confidence interval (CI), margin error (ME): glycerol conversion $\pm 1.2 \%, 1,2$-PD selectivity $\pm 2.3 \%$, acetol selectivity $\pm 0.8 \%$, ethylene glycol (EG) selectivity $\pm 1.0 \%$, others selectivity $\pm 2.0 \%$.

Figure 6 illustrates the glycerol conversion and the yields of different products over the reaction time. It can be clearly observed that when the Pd loading onto the CZA catalyst was increased from $0 \mathrm{wt} \%(\mathrm{CZA})$ to $2 \mathrm{wt} \%$, the glycerol was converted more 
rapidly as the glycerol conversions over the reaction time were all higher with a $2 \mathrm{wt} \% \mathrm{Pd}$ promoted catalyst; when the Pd loading was further increased to $3 \mathrm{wt} \%$, the conversion over the reaction time was not significantly changed (Figure 6a). Using the catalyst with $2 \mathrm{wt} \% \mathrm{Pd}$ loaded, the specific glycerol conversion rate after $1 \mathrm{~h}$ reaction was more than five times higher compared with the CZA catalyst without loading Pd as listed in Table S1 in the supplementary documents. In our previous work, it has been reported that the number of strong acidic sites is associated to the $\mathrm{Cu}$ surface area [35]. By adding 5\% $\mathrm{Ni}$ (molar) onto a $\mathrm{Cu} / \mathrm{ZnO} / \mathrm{Al}_{2} \mathrm{O}_{3}$ catalyst, the 1,2-PD selectivity was improved but the glycerol dehydration rate was reduced due to the loss of a strong acidic site and $\mathrm{Cu}$ surface area by the addition of $\mathrm{Ni}$, which was inactive for glycerol dehydration [35]. However, it was found in the earlier physicochemical property discussion (Section 2.1.1) that the addition of $2 \mathrm{wt} \% \mathrm{Pd}$ did not significantly change the acidity and $\mathrm{Cu}$ surface area of the CZA catalyst. Thus the increment of the glycerol conversion cannot be explained by the changes of acidity and $\mathrm{Cu}$ surface area caused by the introduction of $\mathrm{Pd}$. The higher glycerol conversion obtained with $\mathrm{Pd}$ added can be attributed to the enhanced catalytic activity on acetol hydrogenation due to the spillover effect and that $\mathrm{Pd}$ is also active for dehydration. It has been widely reported that a higher hydrogen storage capacity of the catalyst can be gained with a small amount of Pd doped onto a $\mathrm{Cu}$ based catalyst as the hydrogen can be easily stored in the form of $\mathrm{PdH}_{\mathrm{x}}$ interstitial hydride [48,49]. The surface hydrogen atoms on the Pd surface can easily diffuse to the adjacent $\mathrm{Cu}$ surface providing more active sites for acetol hydrogenation. Since glycerol dehydration has been generally accepted to be an equilibrium limited reaction [33,40,41], the rapid removal of acetol will allow the equilibrium of glycerol dehydration to be shifted further to the forward direction resulting in a higher glycerol conversion. Figure $6 \mathrm{~b}$ demonstrates that the yield of acetol, which is the intermediate of this reaction system, always increased first and then decreased over the reaction time. When a higher amount of Pd was loaded onto the CZA catalyst, the acetol yield reached its maxima at an earlier stage of the reaction (i.e., $30 \mathrm{~min}$ to $9.8 \%$ acetol yield for $3 \mathrm{Pd}-\mathrm{CZA}$ and $45 \mathrm{~min}$ to $8.5 \%$ acetol yield for $2 \mathrm{Pd}-\mathrm{CZA}$ ) and then more rapidly reduced to a lower value as the reaction proceeded. However, when the unpromoted CZA catalyst was used, the acetol yield increased to $11.7 \%$ after $4 \mathrm{~h}$ reaction and slowly decreased to $5.6 \%$ after $6 \mathrm{~h}$ reaction. Thus, the lower concentration and shorter residence time of acetol can accelerate the glycerol dehydration reaction by shifting the equilibrium of the dehydration reaction forward. Accordingly, the yields of 1,2-PD over reaction time were also higher with more Pd loaded (Figure 6c). More investigation for the promoting effect of Pd on the acetol hydrogenation activity of a CZA catalyst will be discussed in the next section (Section 2.2.2) on acetol hydrogenation. In addition, by carrying out the experiment using the $2 \mathrm{Pd}-\mathrm{ZnO}$ catalyst, it was interesting to see in Figure 6a that glycerol conversions over the reaction time are higher than the glycerol conversions using the CZA catalyst. Since it was reported that $\mathrm{ZnO}$ is not active for glycerol dehydration $[35,63]$, the results suggest that $\mathrm{Pd}$ is active for glycerol dehydration, which has also been reported by a number of publications using supported Pd for glycerol hydrogenolysis with molecular hydrogen [64-66]. Hence, the addition of Pd onto the CZA catalyst can promote glycerol dehydration and hence contribute to a higher glycerol conversion rate with $\mathrm{Pd}$ added. When the $2 \mathrm{Pd}-\mathrm{ZnO}$ catalyst was used, the acetol yield over the reaction time was significantly higher than those using other CZA catalysts with different amounts of Pd loaded, as illustrated in Figure 6b. Therefore, the 1,2-PD selectivity using the $2 \mathrm{Pd}-\mathrm{ZnO}$ catalyst was lower compared with other CZA supported Pd catalysts, as indicated in Table 2 . This finding suggests that the promoting effect of $\mathrm{Pd}$ is primarily due to the synergetic interaction between $\mathrm{Pd}$ and $\mathrm{Cu}$ resulting in the spillover of atomic hydrogen from $\mathrm{Pd}$ to $\mathrm{Cu}$ surface for hydrogenation $[44,48,49,54]$. The selectivities to ethylene glycol (EG) for the catalysts are shown in Table 2. The yields of EG over the reaction time were increased as more Pd was added onto the CZA catalyst (Figure 6d). Since Pd can enhance the $\mathrm{C}-\mathrm{C}$ cleavage, the yield of EG is higher when Pd loading is higher. This has also been 
previously reported by Xia et al. in the study of the promoting effect of Pd on a Cu based catalyst in a glycerol hydrogenolysis using molecular hydrogen [48].
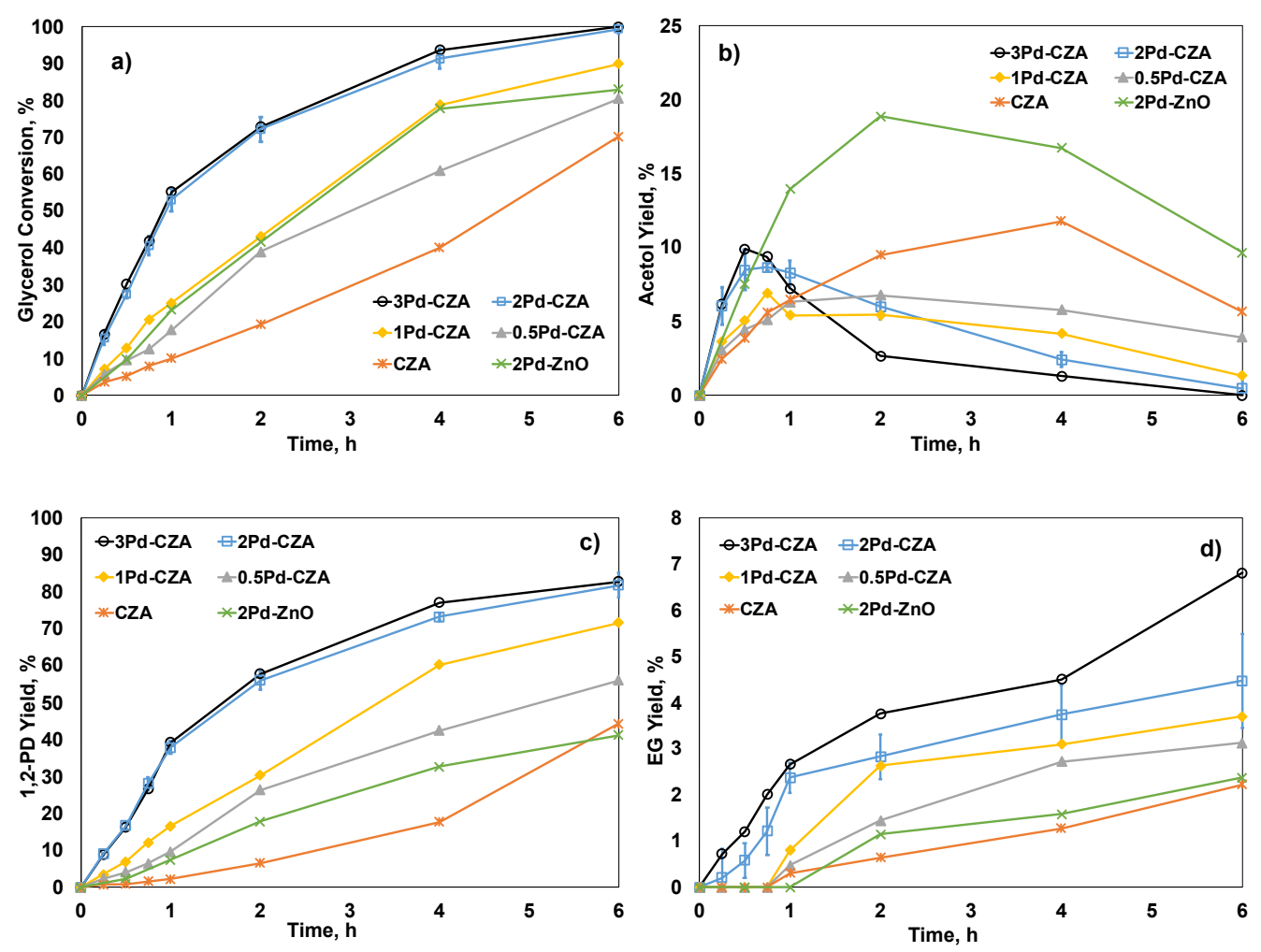

Figure 6. Glycerol conversion and yields of different products over the reaction time using the $\mathrm{Cu} / \mathrm{ZnO} / \mathrm{Al}_{2} \mathrm{O}_{3}$ catalysts with different amounts of Pd loaded: (a) glycerol conversion; (b) acetol yield; (c) 1,2-PD yield; (d) EG yield. Reaction conditions: $220^{\circ} \mathrm{C}, 1.5 \mathrm{MPa} \mathrm{N}, 20 \mathrm{wt} \%$ glycerol, water $/$ methanol molar ratio $=1.2,3 \mathrm{wt} \%$ catalyst with respect to total feed mixture, $6 \mathrm{~h}$ reaction time, 500 RPM. CZA: Cu/Zn/Al (molar) = 35/35/30. Error bars: 95\% CI.

In the earlier section on the TPR study (Section 2.1.2), it was found that Pd can improve the reducibility of a CZA catalyst so that the $\mathrm{CuO}$ can be more rapidly reduced at a relatively lower temperature if a small amount of $\mathrm{Pd}$ is added onto the catalyst. Since it has been generally accepted that the metallic copper is the primary active phase for both glycerol dehydration and acetol hydrogenation, a pre-reduction step is required in all reported processes using a $\mathrm{Cu}$ based catalyst $[67,68]$. In order to investigate the promoting effect of Pd on the reducibility of the CZA catalyst in a reaction system, glycerol hydrogenolysis using unreduced catalysts was carried out. As listed in Table 2 it is interesting to note that using the unreduced 2Pd-CZA catalyst, the glycerol conversion almost reached 100\%, which was close to the glycerol conversion using a reduced catalyst while the unreduced CZA catalyst has very low activity for glycerol conversion. This suggests that $\mathrm{CuO}$ on $2 \mathrm{Pd}-\mathrm{CZA}$ was likely reduced in situ at the reaction temperature, which was $220^{\circ} \mathrm{C}$. Since no external hydrogen was supplied, hydrogen was formed in situ in the reaction system by the unreduced 2Pd-CZA catalyst. Choi and Stenger stated that all the three oxidation states of $\mathrm{Cu}\left(\mathrm{Cu}^{0}, \mathrm{Cu}^{+}\right.$and $\left.\mathrm{Cu}^{2+}\right)$ were active in a methanol steam reforming reaction system [69]. In the recently reported methanol steam reforming processes, catalyst reduction prior to the reaction is usually needed to obtain a higher $\mathrm{H}_{2}$ yield when a $\mathrm{Cu}$ based catalyst or a Pd promoted $\mathrm{Cu}$ based catalyst is used [45,70]. Although the unreduced catalysts are normally found to be less active than the reduced catalysts [71], the hydrogen yielded using an unreduced catalyst can still in situ reduce the $\mathrm{PdO}$ and subsequently reduce the $\mathrm{CuO}$ catalyst due to the spillover effect. Based on the finding in the TPR study in the earlier section (Section 2.1.2) the reduction of Pd doped CZA catalyst by molecular hydrogen 
starts at $45^{\circ} \mathrm{C}$ and completes at $200{ }^{\circ} \mathrm{C}$ with its highest reduction rate at $133{ }^{\circ} \mathrm{C}$. Therefore, $\mathrm{PdO}$ can be reduced in situ by the in situ hydrogen and promote the reduction of $\mathrm{CuO}$ at the reaction temperature, which is $220^{\circ} \mathrm{C}$ during the reaction time. However, the selectivity of 1,2-PD using an unreduced 2Pd-CZA catalyst was only $77.3 \%$, which was lower than that using a reduced catalyst $(82.4 \%)$. As previously mentioned, the byproducts are formed via the side reactions when the availability of hydrogen from methanol steam reforming is insufficient for acetol hydrogenation. At the early stage of the reaction, an unreduced catalyst could be less active for methanol steam reforming than a reduced catalyst resulting in a lower hydrogen availability [71]. In addition, the in situ reduction of $\mathrm{PdO}$ and $\mathrm{CuO}$ could also consume a fraction of hydrogen produced from methanol steam reforming, further lowering the availability of hydrogen for acetol hydrogenation hence resulting in a lower 1,2-PD selectivity. As observed in Figure 7a, the glycerol conversion using an unreduced $2 \mathrm{Pd}-\mathrm{CZA}$ catalyst at the early stage of the reaction was lower than that using a reduced catalyst. This is possibly due to the fact that $\mathrm{CuO}$ was not completely reduced as $\mathrm{CuO}$ is less active for glycerol dehydration [67,72]. Also insufficient amount of hydrogen for acetol hydrogenation could cause higher acetol yield at the early stage of the reaction as observed in Figure $7 \mathrm{~b}$ resulting in a lower 1,2-PD selectivity as listed in Table 2 compared with that using a reduced $2 \mathrm{Pd}-\mathrm{CZA}$ catalyst. When an unreduced CZA catalyst was used, the glycerol conversion was only $11.0 \%$ while the glycerol conversion was $70.2 \%$ using a reduced CZA catalyst (Table 2), revealing that $\mathrm{CuO}$ was remarkably less active for glycerol dehydration than metallic $\mathrm{Cu}$ due to the fact the unreduced CZA catalyst could not be effectively reduced at the reaction temperature. This finding is in good agreement with the TPR data shown in Section 2.1.2 where the reduction of the CZA catalyst starts at $190{ }^{\circ} \mathrm{C}$ and the maximum hydrogen consumption rate occurs at $270{ }^{\circ} \mathrm{C}$. At $220^{\circ} \mathrm{C}$, only a trace amount of $\mathrm{CuO}$ could be possibly reduced by the in situ hydrogen over the reaction time resulting in a lower activity for glycerol dehydration. The in situ reduction of the Pd-CZA catalyst at a lower temperature promoted by Pd could also contribute to the higher catalytic activity of a Pd promoted CZA catalyst. It has been reported when large amounts of water and methanol were present in the reaction mixture, it is difficult to completely remove the oxygen dissolved in a mixture of glycerol, water and methanol [73]. This trace oxygen could oxidize the surface $\mathrm{Cu}$ causing the deactivation of the catalyst during the reaction [74]. Thus, the in situ reduction of $\mathrm{CuO}$ at the reaction temperature induced by the addition of $\mathrm{Pd}$ could prevent the loss of catalytic activity due to any possible oxidation of the catalyst during the reaction.
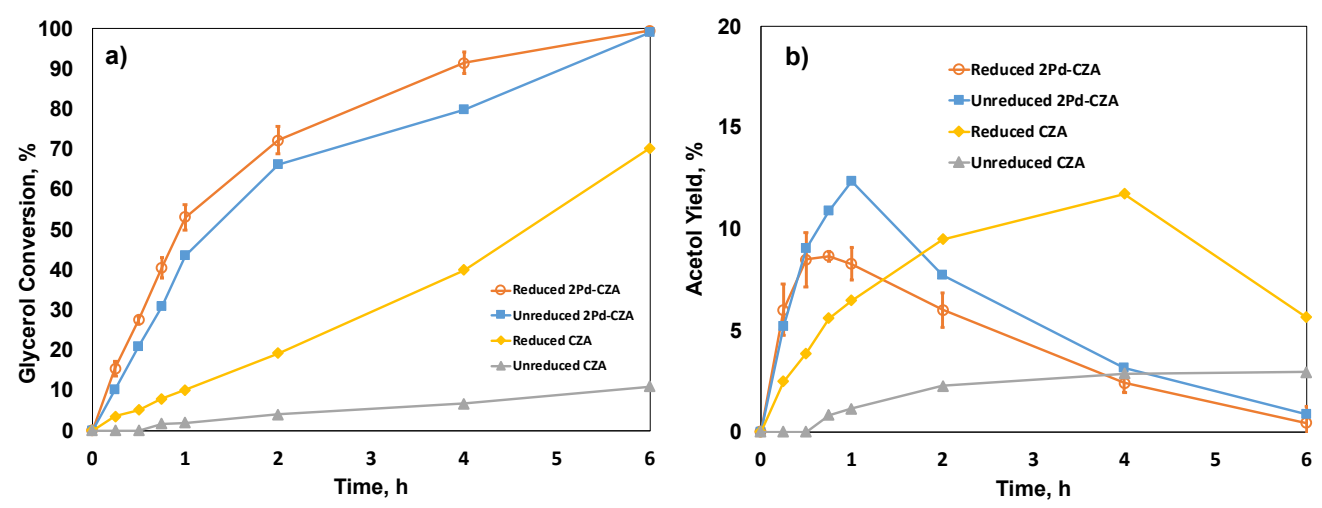

Figure 7. Effect of $\mathrm{Pd}$ on the unreduced CZA catalytic activity and compared with the reduced catalysts in glycerol hydrogenolysis with in situ hydrogen from methanol steam reforming: (a) glycerol conversion; (b) acetol yield. Reaction conditions: $220{ }^{\circ} \mathrm{C}, 1.5 \mathrm{MPa} \mathrm{N}$, $20 \mathrm{wt} \%$ glycerol, water $/$ methanol molar ratio $=1.2,3 \mathrm{wt} \%$ catalyst with respect to total feed mixture, $6 \mathrm{~h}$ reaction time, 500 RPM. CZA: Cu/Zn/Al (molar) = 35/35/30. Error bars: 95\% CI. 
2.2.2. Effect of $\mathrm{Pd}$ on the Catalytic Activities of $\mathrm{Cu} / \mathrm{ZnO} / \mathrm{Al}_{2} \mathrm{O}_{3}$ Catalysts for Acetol Hydrogenation Using Externally Supplied Molecular Hydrogen

Since the improvements of glycerol conversion and 1,2-PD selectivity by addition of Pd onto a CZA catalyst is found to be attributed to the enhancement of the catalyst activity for acetol hydrogenation, some experiments of acetol hydrogenation using the CZA catalyst and 2Pd-CZA catalyst with externally supplied molecular hydrogen were carried out. The results were compared to examine the promoting effect of Pd on the catalytic activity for acetol hydrogenation. The activity comparison is shown in Table 3. It was found that when the initial acetol concentration was increased from $10 \%$ to $20 \%$ under the same reaction conditions, the 1,2-PD selectivities were all significantly decreased regardless of Pd addition due to higher selectivities of other byproducts. No EG was formed, suggesting that the EG was formed only via $\mathrm{C}-\mathrm{C}$ cleavage of glycerol; this finding has been reported previously $[35,68]$. All the byproducts were believed to be formed via the side reactions caused by acetol. With a $10 \%$ aqueous acetol solution as the feedstock, at 2.8 $\mathrm{MPa}$ hydrogen pressure, the 1,2-PD selectivity was $92.7 \%$ using a CZA catalyst and $95.6 \%$ using a $2 \mathrm{Pd}-\mathrm{CZA}$ catalyst. When the initial acetol concentration was increased to $20 \%$, the 1 ,2-PD selectivity dropped to $55.6 \%$ using a CZA catalyst and $80.9 \%$ using a 2 Pd-CZA catalyst. In addition, the selectivities of other byproducts were $44.4 \%$ and $18.7 \%$, respectively, using $20 \%$ aqueous acetol feedstock, which were higher compared to the other byproducts selectivities when $10 \%$ aqueous acetol was used. Therefore, a higher acetol concentration in the reaction mixture will result in a higher selectivity of other byproducts, hence resulting in a lower 1,2-PD selectivity. This result is in an agreement with the findings in the previous section that the higher acetol concentration and longer residence time in the reaction mixture can result in a higher selectivity of other byproducts. Furthermore, when $2 \mathrm{wt} \% \mathrm{Pd}$ was added, the 1,2-PD selectivity was clearly improved under the same hydrogen pressure. It was noticed that using the $2 \mathrm{Pd}-\mathrm{CZA}$ catalyst the acetol hydrogenation rate was remarkably increased and the acetol reached a complete conversion in a shorter reaction time compared with using the CZA catalyst as shown in Figure 8. By comparing the specific rate of acetol conversion after $1 \mathrm{~h}$ reaction time as listed in Table 3 (also see Table S2), using a $10 \mathrm{wt} \%$ aqueous acetol solution as the feedstock the acetol conversion rate with the $2 \mathrm{Pd}-\mathrm{CZA}$ catalyst was about 2.5 times higher than that using a CZA catalyst under the same hydrogen pressure; when the aqueous acetol feed concentration was increased to $20 \mathrm{wt} \%$ the specific acetol conversion rate was nearly three times higher using the $2 \mathrm{Pd}-\mathrm{CZA}$ catalyst. This clearly reveals that acetol can be more rapidly hydrogenated when $\mathrm{Pd}$ is used as the promoter under the same hydrogen pressure. It was further noticed that at $2.8 \mathrm{MPa}$ hydrogen pressure using a $2 \mathrm{Pd}-\mathrm{CZA}$ catalyst and $20 \%$ aqueous acetol as the feedstock, the effectiveness of acetol hydrogenation was higher than using a CZA catalyst at $4.2 \mathrm{MPa}$ hydrogen pressure since a Pd promoted CZA catalyst reached $100 \%$ acetol conversion in a shorter time (Figure $8 \mathrm{~b}$ ) and the 1,2-PD selectivity is higher (Table 3). This finding suggests that when Pd is added onto a CZA catalyst, the acetol can be more effectively hydrogenated under a relatively lower hydrogen pressure compared with using an unpromoted catalyst. Therefore, these results indicate glycerol hydrogenolysis with in situ hydrogen with a Pd promoted CZA catalyst can improve acetol hydrogenation. Essentially the amount of acetol present in the reaction mixture can be kept at a lower level over the reaction time and the glycerol conversion and 1,2-PD selectivity can be improved. 
Table 3. Promoting effect of Pd on CZA catalysts for acetol hydrogenation ${ }^{1}$.

\begin{tabular}{|c|c|c|c|c|c|c|}
\hline \multirow[b]{2}{*}{ Catalysts } & \multirow[b]{2}{*}{$\begin{array}{c}\text { Acetol Concentration } \\
\text { wt } \%\end{array}$} & \multirow{2}{*}{$\begin{array}{c}\text { Hydrogen Pressure } \\
\text { Mpa }\end{array}$} & \multirow[b]{2}{*}{$\underset{\%}{\text { Acetol Conversion }}$} & \multicolumn{2}{|c|}{ Selectivity } & \multirow{2}{*}{$\begin{array}{c}\text { 1st Hour Specific Rate of } \\
\text { Acetol Conversion } \\
\text { mmol } \cdot h^{-1} \cdot \text { gcat }^{-1}\end{array}$} \\
\hline & & & & $\begin{array}{c}\text { 1,2-PD } \\
\%\end{array}$ & $\begin{array}{l}\text { Others } \\
\%\end{array}$ & \\
\hline $\mathrm{CZA}^{2}$ & 10 & 2.8 & 92.9 & 92.7 & 7.3 & 106.64 \\
\hline $2 \mathrm{Pd}-\mathrm{CZA}^{3}$ & 10 & 2.8 & 100.0 & 95.6 & 3.9 & 263.72 \\
\hline $\mathrm{CZA}^{2}$ & 20 & 2.8 & 92.0 & 55.6 & 44.4 & 80.64 \\
\hline $2 \mathrm{Pd}-\mathrm{CZA}^{3}$ & 20 & 2.8 & 99.3 & 80.9 & 18.7 & 225.88 \\
\hline $\mathrm{CZA}^{2}$ & 20 & 4.2 & 100.0 & 70.6 & 29.4 & 138.31 \\
\hline $2 \mathrm{Pd}-\mathrm{CZA}^{3}$ & 20 & 4.2 & 100.0 & 85.8 & 14.0 & 254.66 \\
\hline
\end{tabular}

${ }^{1}$ Reaction conditions: $200{ }^{\circ} \mathrm{C}, 500 \mathrm{RPM}, 6 \mathrm{~h}$ reaction time, $5 \mathrm{wt} \%$ of catalyst with respect to acetol weight, aqueous acetol solution.

${ }^{2} \mathrm{Cu} / \mathrm{Zn} / \mathrm{Al}$ (molar) $=35 / 35 / 30 .{ }^{3}$ Support: $\mathrm{CZA}^{2}$.
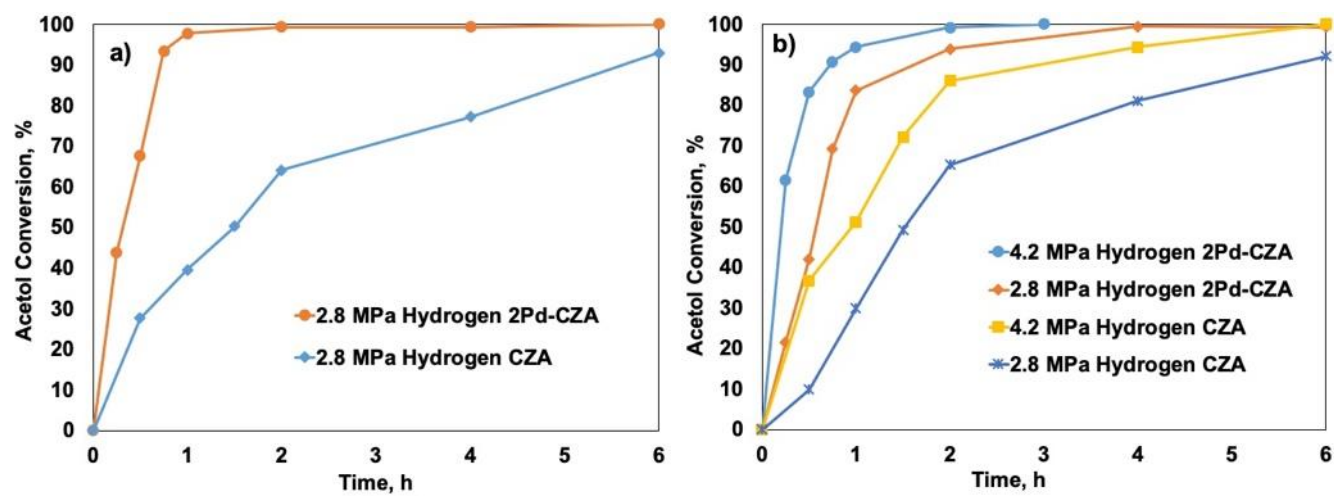

Figure 8. Promoting effect of $2 \mathrm{wt} \% \mathrm{Pd}$ on a CZA catalyst for acetol hydrogenation: (a) $10 \mathrm{wt} \%$ aqueous acetol; (b) $20 \mathrm{wt} \%$ aqueous acetol. Reaction conditions: $200{ }^{\circ} \mathrm{C}, 500 \mathrm{RPM}, 6 \mathrm{~h}$ reaction time, $5 \mathrm{wt} \%$ of catalyst with respect to acetol weight. $\mathrm{CZA}: \mathrm{Cu} / \mathrm{Zn} / \mathrm{Al}$ (molar) = 35/35/30.

It was also noticed in Table 3 that the 1,2-PD selectivities are apparently improved when the hydrogen pressures are increased from 2.8 to $4.2 \mathrm{MPa}$ for both CZA and Pd promoted CZA catalyst. This can be due to the higher acetol hydrogenation rate at higher hydrogen pressure as illustrated in Figure $8 \mathbf{b}$ as well as listed in Table 3, thus suppressing the side reactions caused by acetol, which has also been investigated and reported in our previous work [5]. In a glycerol hydrogenolysis process, since no external hydrogen is supplied, the availability of in situ hydrogen from methanol steam reforming also becomes of importance, which has been extensively reported. It has been extensively studied and reported in Lemonidou's group's works that the availability of hydrogen from methanol steam reforming can strongly affect the 1,2-PD selectivity using the CZA catalyst [9,68]. Pd has been well known as an effective promoter for a $\mathrm{Cu}$ based catalyst for methanol steam reforming, which has been reported in numerous works. Bichon et al. in their work investigated the promoting effect of a $\mathrm{Cu} / \mathrm{ZnO} / \mathrm{Al}_{2} \mathrm{O}_{3}$ catalyst, it was reported that with $0.7 \mathrm{wt} \%$ $\mathrm{Pd}$ loaded onto a $\mathrm{Cu} / \mathrm{ZnO} / \mathrm{Al}_{2} \mathrm{O}_{3}$ catalyst, the methanol conversion can be increased compared with an unpromoted catalyst (approximately by 20\% 30\%) [70]. Azenha et al. in their work compared the activity of $\mathrm{Cu} / \mathrm{ZrO}_{2}$ catalysts with and without Pd loaded, it was claimed that with $4 \mathrm{wt} \% \mathrm{Pd}$ loaded onto the $\mathrm{Cu} / \mathrm{ZrO}_{2}$ catalyst the hydrogen production rates $\left(\mathrm{mmolH}_{2} \cdot \mathrm{hr}^{-1}\right.$.mole-metal $\left.{ }^{-1}\right)$ are approximately twice of those using the unpromoted catalyst at various temperatures [47]. Therefore, for the glycerol hydrogenolysis process with in situ hydrogen from methanol steam reforming, the improvement of the 1,2-PD selectivity using a Pd promoted CZA catalyst, beside the enhancement on the acetol hydrogenation activity of the catalyst, could also be possibly due to the promoting effect of $\mathrm{Pd}$ on methanol steam reforming, resulting a higher amount of in situ hydrogen. 


\subsubsection{Reusability of the Catalyst}

The stability of a catalyst is a very important factor to be considered in its industrial application. In this research, the $2 \mathrm{Pd}-\mathrm{CZA}$ catalyst was recycled and reused to investigate the stability of the catalyst. After the reaction, the catalyst was filtered from the reaction mixture and regenerated at $300{ }^{\circ} \mathrm{C}$ under a flow of high purity hydrogen for $2 \mathrm{~h}$ to reduce the oxidized metallic $\mathrm{Cu}$ due to contacting with air during the recycling procedures since a trace amount of $\mathrm{CuO}$ was observed via the XPS profile in the earlier section (Section 2.1.4). Also, the regeneration step can remove some organic deposition on the catalyst surface during the reaction since the deposition of carbonaceous species onto a $\mathrm{Cu}$ based catalyst has been considered as one of the major reasons for the deactivation of the $\mathrm{Cu}$ based catalyst in glycerol hydrogenolysis [75,76]. The experimental results for the recycled catalysts were listed in Table 4 . When the catalyst was firstly recycled and reused, the glycerol conversion and 1,2-PD selectivity were slightly reduced from $99.4 \%$ to $94.0 \%$ and from $82.4 \%$ to $80.7 \%$, respectively, compared with the results using a fresh catalyst. When the catalyst was further recycled and reused for the second time, the catalyst deactivation was negligible as the glycerol conversion and 1,2-PD selectivity were comparable to the results using the first time recycled catalyst (Table 4). On the third recycle, a slight further decrease in glycerol conversion and 1,2-PD selectivity was observed. A number of studies have reported that the other main cause of $\mathrm{Cu}$ based catalyst deactivation in the glycerol hydrogenolysis process is catalyst sintering resulting in particle aggregation [77,78]. Figure 9 illustrates the XRD profiles of the spent 2Pd-CZA catalysts before reduction up to three times recycles and the results are compared with that of the reduced fresh catalyst. The metallic $\mathrm{Cu}$ was the dominant phase for the reduced fresh catalyst and all the recycled catalysts. $\mathrm{No} \mathrm{CuO}$ peak was observed although a very low intensity peak of $\mathrm{Cu}^{2+}$ was detected for the spent catalyst based on the XPS date (Section 2.1.4). The intensities of the metallic Cu peaks of the recycled catalysts were not significantly changed, therefore, it could be expected that no severe sintering occurred during the reaction. The peak with a very low intensity at $36.4^{\circ}$ overlapping with the peak of $\mathrm{ZnO}$, which was at $36.3^{\circ}$ for the recycled catalysts, probably represents $\mathrm{Cu}_{2} \mathrm{O}$. A trace amount of $\mathrm{Cu}_{2} \mathrm{O}$ formation is possibly due to the oxidation of metallic $\mathrm{Cu}$ over the reaction by the trace oxygen dissolved in the reaction mixture $[73,74]$ or the contact with air during the process of recovering the catalyst from the reaction mixture for XRD measurements. The peak of $\mathrm{Cu}_{2} \mathrm{O}$ was not clearly observed for the freshly reduced catalyst. From Table 5, it can be noticed that compared to the fresh catalyst, the $\mathrm{Cu}$ surface area of the firstly recycled catalyst slightly reduced from 17.8 to $14.8 \mathrm{~m}^{2} / \mathrm{g}$-cat and the $\mathrm{Cu}$ particle size obtained via Scherrer's equation from XRD profiles slightly increased from 18.3 to $19.3 \mathrm{~nm}$ suggesting that the catalyst sintering has occurred during the reaction to a slight extent. When the catalyst was further recycled, the $\mathrm{Cu}$ surface area and the $\mathrm{Cu}$ particle size were not significantly changed. The BET surface area also followed a similar trend. As illustrated in Figure 10a, the glycerol conversions over the reaction time were slightly higher using a fresh catalyst than using the firstly recycled catalyst and then became almost unchanged when the catalyst was further recycled two more times. This was possibly due to the reduced $\mathrm{Cu}$ surface area, which is the primary active site for glycerol dehydration after the catalyst was firstly recycled resulting in a lower glycerol conversion rate (Table S3). The acetol selectivity and yield increased significantly when the catalyst was firstly recycled, as shown in Table 4 and Figure 10b, and then became fairly similar when the catalyst was further recycled. The selectivities of other byproducts using spent catalysts were slightly higher than using a fresh catalyst, as indicated in Table 4 . These trends of the physicochemical properties of the catalyst upon recycling (Table 5) are in good agreement with the trend of the catalyst activity demonstrated in Table 4. Thus, slight catalyst sintering occurred during the reaction. The presence of alumina likely plays an important role in the stability of the catalyst as it can isolate the individual metal particles to prevent their aggregation over the reaction $[34,79]$. 
Table 4. Activities of the recycled catalysts ${ }^{1}$.

\begin{tabular}{cccccc}
\hline Catalyst & $\begin{array}{c}\text { Glycerol } \\
\text { Conversion } \\
\mathbf{\%}\end{array}$ & $\begin{array}{c}\mathbf{1 , 2 - P D} \\
\mathbf{\%}\end{array}$ & $\begin{array}{c}\text { Acetol } \\
\mathbf{\%}\end{array}$ & $\begin{array}{c}\text { EG } \\
\mathbf{\%}\end{array}$ & $\begin{array}{c}\text { Others } \\
\mathbf{\%}\end{array}$ \\
\cline { 3 - 6 } & 99.4 & 82.4 & 0.4 & 4.5 & 12.7 \\
Fresh ${ }^{2}$ & 94.0 & 80.7 & 1.8 & 4.0 & 13.5 \\
First Recycle & 94.0 & 81.0 & 1.8 & 4.4 & 12.7 \\
Second Recycle & 92.4 & 78.6 & 1.7 & 3.9 & 15.8 \\
Third Recycle & &
\end{tabular}

${ }^{1}$ Reaction conditions: $220^{\circ} \mathrm{C}, 1.5 \mathrm{MPa} \mathrm{N}_{2}, 20 \mathrm{wt} \%$ glycerol, water/methanol molar ratio $=1.2,3 \mathrm{wt} \%$ catalyst with respect to total feed mixture, $6 \mathrm{~h}$ reaction time, $500 \mathrm{RPM}$. Catalyst: $2 \mathrm{Pd}-\mathrm{CZA}, \mathrm{Cu} / \mathrm{Zn} / \mathrm{Al}$ (molar) =35/35/30 $295 \%$ Confidence interval, margin error (ME): glycerol conversion $\pm 1.2 \%, 1,2$-PD selectivity $\pm 2.3 \%$, acetol selectivity $\pm 0.8 \%$, EG selectivity $\pm 1.0 \%$, others selectivity $\pm 2.0 \%$.

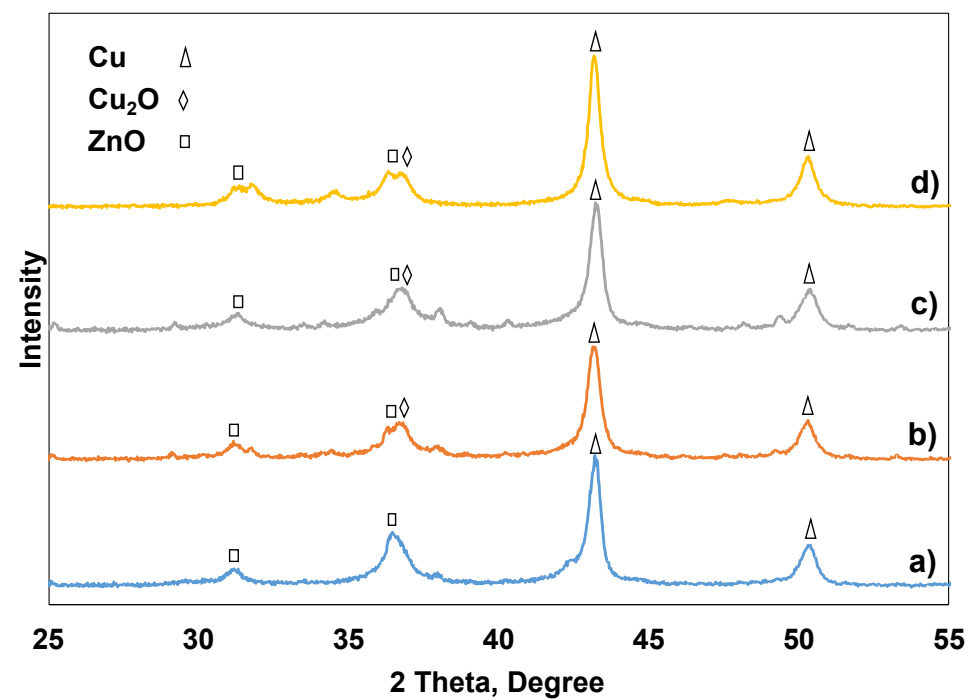

Figure 9. XRD profiles of 2Pd-CZA catalysts: (a) reduced fresh catalyst; (b) first time recycle; (c) second time recycle; $(\mathbf{d})$ third time recycle. Spent catalysts were not reduced. $\mathrm{Cu} / \mathrm{Zn} / \mathrm{Al}$ (molar) = 35/35/30. All traces have been displaced for clarity.

Table 5. Physicochemical properties of recycled catalysts ${ }^{1}$.

\begin{tabular}{cccc}
\hline Catalyst & $\begin{array}{c}\text { Cu Particle Size }{ }^{2} \\
(\mathbf{n m})\end{array}$ & $\begin{array}{c}\text { Cu Surface Area } \\
\left(\mathbf{m}^{2} / \mathbf{g} \text {-cat }\right)\end{array}$ & $\begin{array}{c}\text { BET Surface Area } \\
\left(\mathbf{m}^{2} / \mathbf{g} \text {-cat }\right)\end{array}$ \\
\hline Fresh & 18.3 & 17.8 & 84.6 \\
First Recycle & 19.3 & 14.8 & 79.1 \\
Second Recycle & 19.5 & 13.2 & 74.2 \\
Third Recycle & 19.4 & 12.5 & 62.9 \\
\hline
\end{tabular}

${ }^{1}$ Reaction conditions: $220{ }^{\circ} \mathrm{C}, 1.5 \mathrm{MPa} \mathrm{N}, 20 \mathrm{wt} \%$ glycerol, water/methanol molar ratio $=1.2,3 \mathrm{wt} \%$ catalyst with respect to total feed mixture, $6 \mathrm{~h}$ reaction time, $500 \mathrm{RPM}$. Catalyst: $2 \mathrm{Pd}-\mathrm{CZA}, \mathrm{Cu} / \mathrm{Zn} / \mathrm{Al}$ (molar) =35/35/30.

${ }^{2}$ Calculated via the Scherrer equation based on the XRD profiles. 

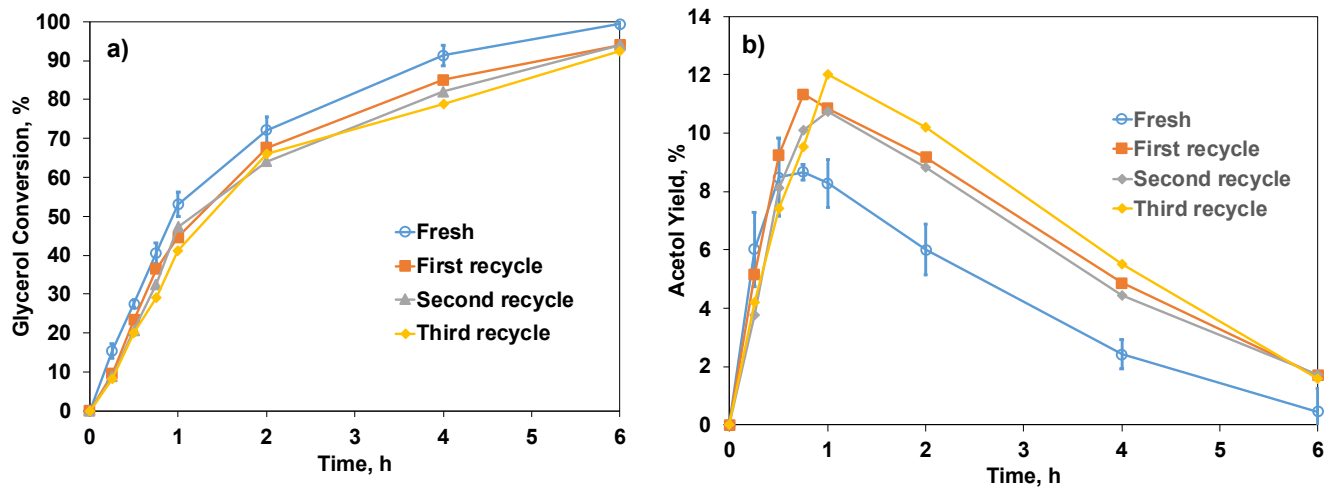

Figure 10. Activities of the recycled catalysts: (a) glycerol conversion; (b) acetol yield. Reaction conditions: $220^{\circ} \mathrm{C}, 1.5 \mathrm{MPa}$ $\mathrm{N}_{2}, 20 \mathrm{wt} \%$ glycerol, water/methanol molar ratio $=1.2,3 \mathrm{wt} \%$ catalyst with respect to total feed mixture, $6 \mathrm{~h}$ reaction time, 500 RPM. Catalyst: 2Pd-CZA, Cu/Zn/Al (molar) = 35/35/30. Error bars: 95\% CI.

\section{Materials and Methods}

\subsection{Materials and Methods for Catalyst Preparations}

All chemicals were purchased from Sigma-Aldrich Co. Canada (Oakville, ON, Canada) and all the gases were purchased from Praxair Canada Inc. (Mississauga, ON, Canada). The preparation method of the CZA catalyst via oxalate gel-coprecipitation has been previous reported by our group [34], the optimum molar ratio of $\mathrm{Cu}: \mathrm{Zn}: \mathrm{Al}$ (35:35:30) has also been determined previously and is used throughout this work [35]. The Pd was loaded onto a calcined $\mathrm{Cu} / \mathrm{ZnO} / \mathrm{Al}_{2} \mathrm{O}_{3}$ and commercial $\mathrm{ZnO}$ catalyst support via an impregnation method. All the catalyst supports were dried at $110{ }^{\circ} \mathrm{C}$ for more than $12 \mathrm{~h}$ (overnight) to remove the moisture before Pd impregnation. A designated amount of palladium (II) acetate $(\geq 98 \%)$ was placed into a round bottom flask and dissolved with the pre-calculated amount of acetone (ACS reagent grade) needed to meet $35 \mathrm{~mL}$ solvent per gram of catalyst support. Then the catalyst support was weighed and placed into the palladium acetate solution and aged for $6 \mathrm{~h}$. The flask was then placed in a water batch at $70{ }^{\circ} \mathrm{C}$ under vigorous stirring until the solvent was completely evaporated. The catalyst was then dried in an oven at $110{ }^{\circ} \mathrm{C}$ overnight. The dried particles were ground and screened via a sieve with $250 \mu \mathrm{m}$ opening and then calcined in stationary air at $360^{\circ} \mathrm{C}$ for $4 \mathrm{~h}$. The percentages of the Pd loading through this work are all on weight fraction basis.

\subsection{Materials and Methods for Catalyst Characterizations}

Temperature programmed reduction (TPR), temperature programmed desorption (TPD) and $\mathrm{N}_{2} \mathrm{O}$ reactive frontal chromatography (RFC) analyses were carried out by an Altamira AMI-200 instrument (Pittsburgh, PA, USA) equipped with a thermal conductivity detector (TCD). Approximately $100 \mathrm{mg}$ of catalyst powder was weighed and transferred into a U shape quartz tube. For the TPR analysis, the catalyst was pre-treated at $200{ }^{\circ} \mathrm{C}$ for $60 \mathrm{~min}$ being flushed by a continuous argon stream at a flow rate of $30 \mathrm{~mL} / \mathrm{min}$ to remove all the moisture and other physically absorbed species on the catalyst surface. Then the catalyst was cooled down to $25^{\circ} \mathrm{C}$ by an argon stream and heated under a $60 \mathrm{~mL} / \mathrm{min}$ stream of $5 \% \mathrm{H}_{2}$ balanced with argon at a heating rate of $5{ }^{\circ} \mathrm{C} / \mathrm{min}$ until $800{ }^{\circ} \mathrm{C}$. The characteristic $\mathrm{P}$ values were calculated to ensure all the experiments were performed in absence of significant reducing gas concentration gradients along the tube [80]. To analyze the acidity of the catalyst by the $\mathrm{NH}_{3}$ TPD technique, the catalyst was firstly reduced under a flow of $5 \% \mathrm{H}_{2}$ balanced with argon at a volumetric flow of $30 \mathrm{~mL} / \mathrm{min}$ at $300{ }^{\circ} \mathrm{C}$ for $2 \mathrm{~h}$. Then the catalyst bed was then cooled down to $25^{\circ} \mathrm{C}$ and 20 pulses of $5 \% \mathrm{NH}_{3}$ balanced with argon were injected into the catalyst be to ensure that all the acidic sites of the catalyst are saturated with $\mathrm{NH}_{3}$. The catalyst bed was then heated to $1000{ }^{\circ} \mathrm{C}$ at a heating rate of $10{ }^{\circ} \mathrm{C} / \mathrm{min}$ for $\mathrm{NH}_{3}$ desorption. The $\mathrm{Cu}$ surface area of a catalyst was determined by a $\mathrm{N}_{2} \mathrm{O}$ RFC technique. The catalyst in the tube was firstly reduced by 
a flow of $5 \% \mathrm{H}_{2}$ balanced with argon at $300{ }^{\circ} \mathrm{C}$ for two hours to reduce all the $\mathrm{CuO}$ to metallic $\mathrm{Cu}$, the flow rate of the stream was $30 \mathrm{~mL} / \mathrm{min}$. The catalyst was then cooled down to $60{ }^{\circ} \mathrm{C}$ and the surface $\mathrm{Cu}^{0}$ was oxidized to $\mathrm{Cu}^{+}$by a flow of $1 \% \mathrm{~N}_{2} \mathrm{O}$ balanced with argon gas stream at a flow rate of $30 \mathrm{~mL} / \mathrm{min}$. Then a TPR program was carried out as described before to reduce the surface $\mathrm{Cu}^{+}$to $\mathrm{Cu}^{0}$. The surface copper atom density of $1.46 \times 10^{19}$ atoms $/ \mathrm{m}^{2}$ was used for the $\mathrm{Cu}$ surface area calculation [81]. The X-ray diffraction (XRD) analyses were carried out by a Bruker D8 Focus model (Madison, WI, USA) with $\mathrm{Cu} k \alpha$ radiation and a wavelength of $1.54 \AA$; the $2 \theta$ angle was between $25^{\circ}$ and $55^{\circ}$ with a step of $0.02^{\circ}$ and a ramp of $5^{\circ}$ per minute. BET surface areas of the catalysts were determined by a Gemini 2375 instrument (Norcross, GA, USA) with nitrogen physisorption at $77 \mathrm{~K}$ using a multipoint analysis method. The X-ray photoelectron spectroscopy (XPS) analysis was carried out by Thermo Scientific ESCALab 250 (Hillsboro, OR, USA), which is a multi-technique ultra-high vacuum imaging XPS microprobe spectrometer equipped with a monochromatic $\mathrm{Al} \mathrm{K} \alpha$ source $(1486.6 \mathrm{eV}) \mathrm{X}$-ray source at a typical energy resolution of $0.4-0.5 \mathrm{eV}$ full width at half-maximum (fwhm). The chamber vacuum level was maintained below $2 \times 10^{-10}$ Torr. A $30 \mathrm{mg}$ powder sample was pressed into a pellet with a diameter of $3 \mathrm{~mm}$. Argon ion sputtering was performed at an ion beam energy of $3 \mathrm{keV}$.

\subsection{Catalytic Activity Tests}

All the reactions were carried out in a $300 \mathrm{~mL}$ Parr Instrument 4560 Series mini bench top reactor constructed by Hastelloy (Moline, IL, USA). Unless specified, prior to each reaction, the catalyst was pre-reduced at $300{ }^{\circ} \mathrm{C}$ for $3 \mathrm{~h}$ by a continuous flow of an ultrahigh purity hydrogen in a quartz tube heated by a furnace. The reduced catalyst was then rapidly placed into the reaction mixture. For the reactions with in situ hydrogen via methanol steam reforming, $100 \mathrm{~g}$ of the reaction mixture containing $20 \mathrm{wt} \%$ of glycerol, $32.2 \mathrm{wt} \%$ of water and $47.8 \mathrm{wt} \%$ of methanol was loaded into the reactor. The total volume of the reaction mixture was measured to be $108 \mathrm{~mL}$. The reactor was then flushed with an ultra-high purity nitrogen for three times and pressurized to a designated pressure before heated to the designated reaction temperature. All the reactions were carried out in a batch reaction system. For the acetol hydrogenation reactions with molecular hydrogen, the reactor was flushed three times with an ultra-high purity hydrogen and pressurized to a designated hydrogen pressure at the desired reaction temperature, the pressure was kept constant via feeding molecular hydrogen by a gas cylinder regulator over the reaction time. Liquid samples were taken from a sampling valve and analyzed by an Agilent 6890 gas chromatograph equipped with a flame ionization detector (FID) and a DB-WAX megabore capillary column (Wilmington, DE, USA, $30 \mathrm{~m}, 0.53 \mathrm{~mm}$ I.D., $10 \mu \mathrm{m}$ film thickness). The glycerol conversion, selectivities of all the products and yields of all the products were calculated based on the mole balance of glycerol assuming the glycerol steam reforming does not occur to any significant extend [35]. The equations are supplied in A3 in the supplementary documents.

\section{Conclusions}

In this work, the promoting effect of Pd on a CZA catalyst prepared via the oxalate gel-coprecipitation method was investigated in a glycerol hydrogenolysis process to produce 1,2-PD using in situ hydrogen produced via methanol steam reforming. The 1,2-PD selectivity is greatly improved by adding Pd due to the enhancement on the acetol hydrogenation activity resulting in a reduction of the other undesired byproducts formed from the side reactions of acetol. The rapid removal of acetol can also result in a higher glycerol conversion by shifting the equilibrium of the glycerol dehydration reaction forward. A total of $2 \mathrm{wt} \%$ Pd impregnated onto a CZA catalyst is considered as the optimum amount of Pd loading. In addition, the introduction of $2 \mathrm{wt} \% \mathrm{Pd}$ onto a CZA catalyst can improve the reducibility of the catalyst so that the $\mathrm{CuO}$ can be reduced into metallic $\mathrm{Cu}$ at a lower temperature. This promoting effect of $\mathrm{Pd}$ on the reducibility of $\mathrm{CuO}$ can improve the activity of the catalyst via the in situ reduction of any oxidized $\mathrm{Cu}$ over the reaction time 
since metallic $\mathrm{Cu}$ is considered as the primary active phase for both glycerol dehydration and acetol hydrogenation. The 2Pd-CZA catalyst was found to be slightly deactivated when it was first time recycled due to $\mathrm{Cu}$ aggregation as confirmed by the enlargement of the $\mathrm{Cu}$ particle size and the reduction of the $\mathrm{Cu}$ surface area. After the first recycle, the catalyst deactivation was less noticeable as similar glycerol conversions and 1,2-PD selectivities were obtained.

Supplementary Materials: The following are available online at https:/ / www.mdpi.com/2073-434 4/11/1/110/s1, Table S1: Specific reaction rates of different products yields and glycerol conversion using the CZA catalysts with different Pd loading for glycerol hydrogenolysis with in situ hydrogen from methanol steam reforming; Table S2: Specific reaction rates of acetol conversion using the CZA and 2Pd-CZA catalysts for acetol hydrogenation; Table S3: Specific reaction rates of different products yields and glycerol conversion using recycled 2Pd-CZA catalysts for glycerol hydrogenolysis with in situ hydrogen from methanol steam reforming; A1: Effect of Pd loading onto the CZA catalyst; A2: Repeatability of the reaction process using the 2Pd-CZA catalyst; A3: Mathematical equations for glycerol conversion, product yield, product selectivity, specific rate of glycerol conversion, specific rate of acetol conversion and specific rate of product yield.

Author Contributions: Conceptualization, Y.L. and F.T.T.N.; methodology, Y.L.; validation F.T.T.N.; formal analysis, Y.L. and C.T.Q.M.; writing-original draft preparation, Y.L.; writing—review and editing, F.T.T.N.; supervision, F.T.T.N.; project administration, F.T.T.N.; funding acquisition, F.T.T.N. All authors have read and agreed to the published version of the manuscript.

Funding: This research was funded by Natural Science and Engineer Research Council of Canada (NSERC) Discovery Grant Program.

Institutional Review Board Statement: Not applicable.

Informed Consent Statement: Not applicable.

Data Availability Statement: Data available in a publicly accessible repository.

Conflicts of Interest: The authors declare no conflict of interest.

\section{References}

1. Joo, H.; Kumar, A. Biodiesel Production and Policy. In World Biodiesel Policies and Production, 1st ed.; CRC Press: Boca Raton, FL, USA, 2019; pp. 13-73. [CrossRef]

2. Pagliaro, M.; Rossi, M. The Future of Glycerol, 2nd ed.; The Royal Society of Chemistry: Cambridge, UK, 2010; pp. P001-P170. [CrossRef]

3. Sun, D.; Yamada, Y.; Sato, S.; Ueda, W. Glycerol hydrogenolysis into useful C3 chemicals. Appl. Catal. B 2016, 193, 75-92. [CrossRef]

4. Suppes, G.J. Glycerol Technology Options for Biodiesel Industry. In The Biodiesel Handbook, 2nd ed.; Academic Press and AOCS Press: Urbana, IL, USA, 2010; pp. 439-455. [CrossRef]

5. Liu, Y.; Pasupulety, N.; Gunda, K.; Rempel, G.L.; Ng, F.T.T. Glycerol Hydrogenolysis to 1,2-Propanediol by $\mathrm{Cu} / \mathrm{ZnO} / \mathrm{Al}_{2} \mathrm{O}_{3}$ Catalysts. Top. Catal. 2014, 57, 1454-1462. [CrossRef]

6. Vasiliadou, E.S.; Eggenhuisen, T.M.; Munnik, P.; de Jongh, P.E.; de Jong, K.P.; Lemonidou, A.A. Synthesis and performance of highly dispersed $\mathrm{Cu} / \mathrm{SiO}_{2}$ catalysts for the hydrogenolysis of glycerol. Appl. Catal. B 2014, 145, 108-119. [CrossRef]

7. Nanda, M.R.; Yuan, Z.; Qin, W.; Xu, C. Recent advancements in catalytic conversion of glycerol into propylene glycol: A review. Catal. Rev. Sci. Eng. 2016, 58, 309-336. [CrossRef]

8. Martin, A.; Armbruster, U.; Gandarias, I.; Arias, P.L. Glycerol hydrogenolysis into propanediols using in situ generated hydrogenA critical review. Eur. J. Lipid Sci. Technol. 2013, 115, 9-27. [CrossRef]

9. Yfanti, V.-L.; Lemonidou, A.A. Effect of hydrogen donor on glycerol hydrodeoxygenation to 1,2-propanediol. Catal. Today 2020, 355, 727-736. [CrossRef]

10. Andersson, J.; Grönkvist, S. Large-scale storage of hydrogen. Int. J. Hydrogen Energy 2019, 44, 11901-11919. [CrossRef]

11. Abe, J.O.; Popoola, A.P.I.; Ajenifuja, E.; Popoola, O.M. Hydrogen energy, economy and storage: Review and recommendation. Int. J. Hydrogen Energy 2019, 44, 15072-15086. [CrossRef]

12. D'Hondt, E.; Van, d.V.; Sels, B.F.; Jacobs, P.A. Catalytic glycerol conversion into 1,2-propanediol in absence of added hydrogen. Chem. Commun. 2008, 6011-6012. [CrossRef]

13. Roy, D.; Subramaniam, B.; Chaudhari, R.V. Aqueous phase hydrogenolysis of glycerol to 1,2-propanediol without external hydrogen addition. Catal. Today 2010, 156, 31-37. [CrossRef] 
14. Pendem, C.; Gupta, P.; Chaudhary, N.; Singh, S.; Kumar, J.; Sasaki, T.; Datta, A.; Bal, R. Aqueous phase reforming of glycerol to 1,2-propanediol over Pt-nanoparticles supported on hydrotalcite in the absence of hydrogen. Green Chem. 2012, 14, $3107-3113$. [CrossRef]

15. Liu, S.; Tamura, M.; Shen, Z.; Zhang, Y.; Nakagawa, Y.; Tomishige, K. Hydrogenolysis of glycerol with in-situ produced $\mathrm{H}_{2}$ by aqueous-phase reforming of glycerol using Pt-modified Ir-ReOx $/ \mathrm{SiO}_{2}$ catalyst. Catal. Today 2018, 303, 106-116. [CrossRef]

16. Freitas, I.C.; Manfro, R.L.; Souza, M.M.V.M. Hydrogenolysis of glycerol to propylene glycol in continuous system without hydrogen addition over Cu-Ni catalysts. Appl. Catal. B 2018, 220, 31-41. [CrossRef]

17. Mane, R.B.; Rode, C.V. Simultaneous glycerol dehydration and in situ hydrogenolysis over Cu-Al oxide under an inert atmosphere. Green Chem. 2012, 14, 2780-2789. [CrossRef]

18. Gandarias, I.; Arias, P.L.; Requies, J.; Güemez, M.B.; Fierro, J.L.G. Hydrogenolysis of glycerol to propanediols over a Pt/ASA catalyst: The role of acid and metal sites on product selectivity and the reaction mechanism. Appl. Catal. B 2010, 97, 248-256. [CrossRef]

19. Delgado, S.N.; Yap, D.; Vivier, L.; Especel, C. Influence of the nature of the support on the catalytic properties of Pt-based catalysts for hydrogenolysis of glycerol. J. Mol. Catal. A Chem. 2013, 367, 89-98. [CrossRef]

20. Zhou, C.H.; Deng, K.; Serio, M.D.; Xiao, S.; Tong, D.S.; Li, L.; Lin, C.X.; Beltramini, J.; Zhang, H.; Yu, W.H. Cleaner hydrothermal hydrogenolysis of glycerol to 1,2-propanediol over $\mathrm{Cu}$ /oxide catalysts without addition of external hydrogen. Mol. Catal. 2017, 432, 274-284. [CrossRef]

21. Yin, A.; Guo, X.; Dai, W.; Fan, K. The synthesis of propylene glycol and ethylene glycol from glycerol using Raney Ni as a versatile catalyst. Green Chem. 2009, 11, 1514-1516. [CrossRef]

22. Cortright, R.D.; Davda, R.R.; Dumesic, J.A. Hydrogen from catalytic reforming of biomass-derived hydrocarbons in liquid water. Nature 2002, 418, 964-967. [CrossRef]

23. Musolino, M.G.; Scarpino, L.A.; Mauriello, F.; Pietropaolo, R. Selective transfer hydrogenolysis of glycerol promoted by palladium catalysts in absence of hydrogen. Green Chem. 2009, 11, 1511-1513. [CrossRef]

24. Musolino, M.G.; Scarpino, L.A.; Mauriello, F.; Pietropaolo, R. Glycerol Hydrogenolysis Promoted by Supported Palladium Catalysts. ChemSusChem 2011, 4, 1143-1150. [CrossRef] [PubMed]

25. Gandarias, I.; Arias, P.L.; Requies, J.; El Doukkali, M.; Güemez, M.B. Liquid-phase glycerol hydrogenolysis to 1,2-propanediol under nitrogen pressure using 2-propanol as hydrogen source. J. Catal. 2011, 282, 237-247. [CrossRef]

26. Mauriello, F.; Ariga, H.; Musolino, M.G.; Pietropaolo, R.; Takakusagi, S.; Asakura, K. Exploring the catalytic properties of supported palladium catalysts in the transfer hydrogenolysis of glycerol. Appl. Catal. B 2015, 166-167, 121-131. [CrossRef]

27. Gandarias, I.; Arias, P.L.; Fernández, S.G.; Requies, J.; El Doukkali, M.; Güemez, M.B. Hydrogenolysis through catalytic transfer hydrogenation: Glycerol conversion to 1,2-propanediol. Catal. Today 2012, 195, 22-31. [CrossRef]

28. Xia, S.; Zheng, L.; Wang, L.; Chen, P.; Hou, Z. Hydrogen-free synthesis of 1,2-propanediol from glycerol over Cu-Mg-Al catalysts. RSC Adv. 2013, 3, 16569-16576. [CrossRef]

29. Gandarias, I.; Requies, J.; Arias, P.L.; Armbruster, U.; Martin, A. Liquid-phase glycerol hydrogenolysis by formic acid over $\mathrm{Ni}-\mathrm{Cu} / \mathrm{Al}_{2} \mathrm{O}_{3}$ catalysts. J. Catal. 2012, 290, 79-89. [CrossRef]

30. Gandarias, I.; Fernandez, S.G.; El Doukkali, M.; Requies, J.; Arias, P.L. Physicochemical Study of Glycerol Hydrogenolysis Over a $\mathrm{Ni}-\mathrm{Cu} / \mathrm{Al}_{2} \mathrm{O}_{3}$ Catalyst Using Formic Acid as the Hydrogen Source. Top. Catal. 2013, 56, 995-1007. [CrossRef]

31. Vasiliadou, S.E.; Lemonidou, A.A. Catalytic Glycerol Hydrodeoxygenation under Inert Atmosphere: Ethanol as a Hydrogen Donor. Catalysts 2014, 4, 397-413. [CrossRef]

32. van Ryneveld, E.; Mahomed, A.S.; van Heerden, P.S.; Friedrich, H.B. Direct Hydrogenolysis of Highly Concentrated Glycerol Solutions Over Supported Ru, Pd and Pt Catalyst Systems. Catal. Lett. 2011, 141, 958-967. [CrossRef]

33. Chiu, C.; Tekeei, A.; Ronco, J.M.; Banks, M.; Suppes, G.J. Reducing Byproduct Formation during Conversion of Glycerol to Propylene Glycol. Ind. Eng. Chem. Res. 2008, 47, 6878-6884. [CrossRef]

34. Liu, Y. Catalytic Glycerol Hydrogenolysis to Produce 1,2-propanediol with Molecular Hydrogen and In Situ Hydrogen Produced from Steam Reforming. Ph.D. Thesis, University of Waterloo, Waterloo, ON, Canada, 2014.

35. Liu, Y.; Guo, X.; Rempel, G.L.; Ng, F.T.T. The Promoting Effect of Ni on Glycerol Hydrogenolysis to 1,2-Propanediol with In Situ Hydrogen from Methanol Steam Reforming Using a $\mathrm{Cu} / \mathrm{ZnO} / \mathrm{Al}_{2} \mathrm{O}_{3}$ Catalyst. Catalysts 2019, 9, 412. [CrossRef]

36. Vasiliadou, E.S.; Yfanti, V.-L.; Lemonidou, A.A. One-pot tandem processing of glycerol stream to 1,2-propanediol with methanol reforming as hydrogen donor reaction. Appl. Catal. B 2015, 163, 258-266. [CrossRef]

37. Yfanti, V.-L.; Vasiliadou, E.S.; Lemonidou, A.A. Glycerol hydro-deoxygenation aided by in situ $\mathrm{H}_{2}$ generation via methanol aqueous phase reforming over a Cu-ZnO- $\mathrm{Al}_{2} \mathrm{O}_{3}$ catalyst. Catal. Sci. Technol. 2016, 6, 5415-5426. [CrossRef]

38. Yfanti, V.; Vasiliadou, E.S.; Sklari, S.; Lemonidou, A.A. Hydrodeoxygenation of glycerol with in situ $\mathrm{H}_{2}$ formation over Pt catalysts supported on Fe modified $\mathrm{Al}_{2} \mathrm{O}_{3}$ : Effect of Fe loading. J. Chem. Technol. Biotechnol. 2017, 92, 2236-2245. [CrossRef]

39. Yfanti, V.-L.; Ipsakis, D.; Lemonidou, A.A. Kinetic study of liquid phase glycerol hydrodeoxygenation under inert conditions over a Cu-based catalyst. React. Chem. Eng. 2018, 3, 559-571. [CrossRef]

40. Chiu, C.; Dasari, M.A.; Suppes, G.J.; Sutterlin, W.R. Dehydration of glycerol to acetol via catalytic reactive distillation. AIChE J. 2006, 52, 3543-3548. [CrossRef] 
41. Pala Rosas, I.; Contreras, J.L.; Salmones, J.; Tapia, C.; Zeifert, B.; Navarrete, J.; Vázquez, T.; García, D.C. Catalytic Dehydration of Glycerol to Acrolein over a Catalyst of Pd/LaY Zeolite and Comparison with the Chemical Equilibrium. Catalysts 2017, 7, 73. [CrossRef]

42. Liu, Y.; He, Y.; Zhou, D.; Feng, J.; Li, D. Catalytic performance of Pd-promoted Cu hydrotalcite-derived catalysts in partial hydrogenation of acetylene: Effect of Pd-Cu alloy formation. Catal. Sci. Technol. 2016, 6, 3027-3037. [CrossRef]

43. Hu, B.; Yin, Y.; Liu, G.; Chen, S.; Hong, X.; Tsang, S.C.E. Hydrogen spillover enabled active Cu sites for methanol synthesis from $\mathrm{CO}_{2}$ hydrogenation over Pd doped CuZn catalysts. J. Catal. 2018, 359, 17-26. [CrossRef]

44. Fu, Q.; Luo, Y. Active Sites of Pd-Doped Flat and Stepped $\mathrm{Cu}(111)$ Surfaces for $\mathrm{H}_{2}$ Dissociation in Heterogeneous Catalytic Hydrogenation. ACS Catal. 2013, 3, 1245-1252. [CrossRef]

45. Sá, S.; Silva, H.; Brandão, L.; Sousa, J.M.; Mendes, A. Catalysts for methanol steam reforming-A review. Appl. Catal. B 2010, 99 , 43-57. [CrossRef]

46. Xu, X.; Shuai, K.; Xu, B. Review on Copper and Palladium Based Catalysts for Methanol Steam Reforming to Produce Hydrogen. Catalysts 2017, 7, 183. [CrossRef]

47. Azenha, C.S.R.; Mateos-Pedrero, C.; Queirós, S.; Concepción, P.; Mendes, A. Innovative $\mathrm{ZrO}_{2}$-supported CuPd catalysts for the selective production of hydrogen from methanol steam reforming. Appl. Catal. B 2017, 203, 400-407. [CrossRef]

48. Xia, S.; Yuan, Z.; Wang, L.; Chen, P.; Hou, Z. Hydrogenolysis of glycerol on bimetallic Pd-Cu/solid-base catalysts prepared via layered double hydroxides precursors. Appl. Catal. A 2011, 403, 173-182. [CrossRef]

49. Kim, N.D.; Park, J.R.; Park, D.S.; Kwak, B.K.; Yi, J. Promoter effect of Pd in $\mathrm{CuCr}_{2} \mathrm{O}_{4}$ catalysts on the hydrogenolysis of glycerol to 1,2-propanediol. Green Chem. 2012, 14, 2638-2646. [CrossRef]

50. Feng, Y.; Liu, C.; Kang, Y.; Zhou, X.; Liu, L.; Deng, J.; Xu, H.; Fu, Y. Selective hydrogenolysis of glycerol to 1,2-propanediol catalyzed by supported bimetallic PdCu-KF $/ \gamma-\mathrm{Al}_{2} \mathrm{O}_{3}$. Chem. Eng. J. 2015, 281, 96-101. [CrossRef]

51. Iwasa, N.; Mayanagi, T.; Nomura, W.; Arai, M.; Takezawa, N. Effect of Zn addition to supported Pd catalysts in the steam reforming of methanol. Appl. Catal. A 2003, 248, 153-160. [CrossRef]

52. Cai, F.; Jin, F.; Hao, J.; Xiao, G. Selective hydrogenolysis of glycerol to 1,2-propanediol on Nb-modified Pd-Zr-Al catalysts. Catal. Commun. 2019, 131, 105801. [CrossRef]

53. Li, Y.; Liu, H.; Ma, L.; He, D. Glycerol hydrogenolysis to propanediols over supported Pd-Re catalysts. RSC Adv. 2014, 4, 5503-5512. [CrossRef]

54. Kyriakou, G.; Boucher, M.B.; Jewell, A.D.; Lewis, E.A.; Lawton, T.J.; Baber, A.E.; Tierney, H.L.; Flytzani-Stephanopoulos, M.; Sykes, E.C. Isolated Metal Atom Geometries as a Strategy for Selective Heterogeneous Hydrogenations. Science 2012, 335, $1209-1212$. [CrossRef]

55. Baylet, A.; Marécot, P.; Duprez, D.; Castellazzi, P.; Groppi, G.; Forzatti, P. In situ Raman and in situ XRD analysis of PdO reduction and $\mathrm{Pd}^{0}$ oxidation supported on $\gamma-\mathrm{Al}_{2} \mathrm{O}_{3}$ catalyst under different atmospheres. Phys. Chem. Chem. Phys. 2011, 13, 4607-4613. [CrossRef] [PubMed]

56. Checa, M.; Auneau, F.; Hidalgo-Carrillo, J.; Marinas, A.; Marinas, J.M.; Pinel, C.; Urbano, F.J. Catalytic transformation of glycerol on several metal systems supported on ZnO. Catal. Today 2012, 196, 91-100. [CrossRef]

57. Stevens, J.S.; Schroeder, S.L.M. X-Ray Photoelectron Spectroscopy. In Encyclopedia of Physical Organic Chemistry; John Wiley \& Sons: Hoboken, NJ, USA, 2017; pp. 1-53. [CrossRef]

58. Kim, K.S.; Gossmann, A.F.; Winograd, N. X-ray photoelectron spectroscopic studies of palladium oxides and the palladiumoxygen electrode. Anal. Chem. 1974, 46, 197-200. [CrossRef]

59. Fetisova, A.V.; Kuznetsov, M.V. X-ray photoelectron spectroscopy analysis of electronic states in the oxide layer on an ultradisperse copper surface. J. Appl. Spectrosc. 2009, 76, 523-527. [CrossRef]

60. Espinós, J.P.; Morales, J.; Barranco, A.; Caballero, A.; Holgado, J.P.; González-Elipe, A.R. Interface Effects for $\mathrm{Cu}, \mathrm{CuO}$, and $\mathrm{Cu}{ }_{2} \mathrm{O}$ Deposited on $\mathrm{SiO}_{2}$ and $\mathrm{ZrO}_{2}$. XPS Determination of the Valence State of Copper in $\mathrm{Cu} / \mathrm{SiO}_{2}$ and Cu/ZrO 2 Catalysts. J. Phys. Chem. B 2002, 106, 6921-6929. [CrossRef]

61. Pauly, N.; Tougaard, S.; Yubero, F. Determination of the $\mathrm{Cu} 2 \mathrm{p}$ primary excitation spectra for $\mathrm{Cu}, \mathrm{Cu}_{2} \mathrm{O}$ and $\mathrm{CuO}$. Surf. Sci. 2014, 620, 17-22. [CrossRef]

62. Balamurugan, B.; Mehta, B.R.; Shivaprasad, S.M. Surface-modified CuO layer in size-stabilized single-phase $\mathrm{Cu}_{2} \mathrm{O}$ nanoparticles. Appl. Phys. Lett. 2001, 79, 3176-3178. [CrossRef]

63. Wang, S.; Zhang, Y.; Liu, H. Selective Hydrogenolysis of Glycerol to Propylene Glycol on Cu-ZnO Composite Catalysts: Structural Requirements and Reaction Mechanism. Chem. Asian J. 2010, 5, 1100-1111. [CrossRef]

64. Jiang, T.; Huai, Q.; Geng, T.; Ying, W.; Xiao, T.; Cao, F. Catalytic performance of Pd-Ni bimetallic catalyst for glycerol hydrogenolysis. Biomass Bioenergy 2015, 78, 71-79. [CrossRef]

65. Sun, Q.; Wang, S.; Liu, H. Selective Hydrogenolysis of Glycerol to Propylene Glycol on Supported Pd Catalysts: Promoting Effects of $\mathrm{ZnO}$ and Mechanistic Assessment of Active PdZn Alloy Surfaces. ACS Catal. 2017, 7, 4265-4275. [CrossRef]

66. Li, X.; Zhang, B.; Wu, Q.; Zhang, C.; Yu, Y.; Li, Y.; Lin, W.; Cheng, H.; Zhao, F. A facile strategy for confining ZnPd nanoparticles into a $\mathrm{ZnO@} \mathrm{Al}_{2} \mathrm{O}_{3}$ support: A stable catalyst for glycerol hydrogenolysis. J. Catal. 2016, 337, 284-292. [CrossRef]

67. Sato, S.; Akiyama, M.; Takahashi, R.; Hara, T.; Inui, K.; Yokota, M. Vapor-phase reaction of polyols over copper catalysts. Appl. Catal. A 2008, 347, 186-191. [CrossRef] 
68. Yfanti, V.-L.; Lemonidou, A.A. Mechanistic study of liquid phase glycerol hydrodeoxygenation with in-situ generated hydrogen. J. Catal. 2018, 368, 98-111. [CrossRef]

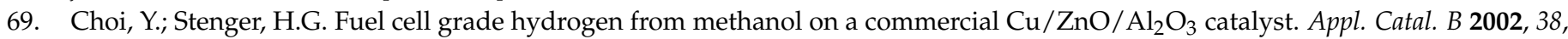
259-269. [CrossRef]

70. Bichon, P.; Asheim, M.; Sperle, A.J.T.; Fathi, M.; Holmen, A.; Blekkan, E.A. Hydrogen from methanol steam-reforming over Cu-based catalysts with and without Pd promotion. Int. J. Hydrogen Energy 2007, 32, 1799-1805. [CrossRef]

71. Matter, P.H.; Ozkan, U.S. Effect of pretreatment conditions on $\mathrm{Cu} / \mathrm{Zn} / \mathrm{Zr}$-based catalysts for the steam reforming of methanol to $\mathrm{H}_{2}$. J. Catal. 2005, 234, 463-475. [CrossRef]

72. Jean, D.; Nohair, B.; Bergeron, J.; Kaliaguine, S. Hydrogenolysis of Glycerol over Cu/ZnO-Based Catalysts: Influence of Transport Phenomena Using the Madon-Boudart Criterion. Ind. Eng. Chem. Res. 2014, 53, 18740-18749. [CrossRef]

73. Kutsche, I.; Gildehaus, G.; Schuller, D.; Schumpe, A. Oxygen solubilities in aqueous alcohol solutions. J. Chem. Eng. Data 1984, 29, 286-287. [CrossRef]

74. Hou, M.; Jiang, H.; Liu, Y.; Chen, R. Role of initial water content in glycerol hydrogenolysis to 1,2-propanediol over Cu-ZnO catalyst. React. Kinet. Mech. Catal. 2017, 122, 1129-1143. [CrossRef]

75. Durán-Martín, D.; Ojeda, M.; Granados, M.L.; Fierro, J.L.G.; Mariscal, R. Stability and regeneration of $\mathrm{Cu}^{\mathrm{Z}} \mathrm{ZrO}_{2}$ catalysts used in glycerol hydrogenolysis to 1,2-propanediol. Catal. Today 2013, 210, 98-105. [CrossRef]

76. Duran-Martin, D.; Granados, M.L.; Fierro, J.L.G.; Pinel, C.; Mariscal, R. Deactivation of CuZn Catalysts Used in Glycerol Hydrogenolysis to Obtain 1,2-Propanediol. Top. Catal. 2017, 60, 1062-1071. [CrossRef]

77. Huang, Z.; Cui, F.; Xue, J.; Zuo, J.; Chen, J.; Xia, C. Cu/SiO 2 catalysts prepared by hom- and heterogeneous depositionprecipitation methods: Texture, structure, and catalytic performance in the hydrogenolysis of glycerol to 1,2-propanediol. Catal. Today 2012, 183, 42-51. [CrossRef]

78. Du, Y.; Wang, C.; Jiang, H.; Chen, C.; Chen, R. Insights into deactivation mechanism of Cu-ZnO catalyst in hydrogenolysis of glycerol to 1,2-propanediol. J. Ind. Eng. Chem. 2016, 35, 262-267. [CrossRef]

79. Bienholz, A.; Blume, R.; Knop-Gericke, A.; Girgsdies, F.; Behrens, M.; Claus, P. Prevention of Catalyst Deactivation in the Hydrogenolysis of Glycerol by $\mathrm{Ga}_{2} \mathrm{O}_{3}$-Modified Copper/Zinc Oxide Catalysts. J Phys. Chem. C 2011, 115, 999-1005. [CrossRef]

80. Bravo-Suarez, J.J.; Subramaniam, B.; Chaudhari, R.V. Ultraviolet-Visible Spectroscopy and Temperature-Programmed Techniques as Tools for Structural Characterization of $\mathrm{Cu}$ in $\mathrm{CuMgAlO}_{\mathrm{x}}$ Mixed Metal Oxides. J. Phys. Chem. C 2012, 116, 18207-18221. [CrossRef]

81. Evans, J.W.; Wainwright, M.S.; Bridgewater, A.J.; Young, D.J. On the determination of copper surface area by reaction with nitrous oxide. Appl. Catal. 1983, 7, 75-83. [CrossRef] 